\title{
POST-REMEDIATION BIOMONITORING OF PESTICIDES IN MARINE WATERS NEAR THE UNITED HECKATHORN SUPERFUND SITE, RICHMOND, CALIFORNIA
}

\author{
L.D. Antrim \\ N.P. Kohn
}

Battelle Marine Sciences Laboratory

Sequim, Washington

July 2000

Prepared for the

U.S. Environmental Protection Agency

Region 9

under a Related Services Agreement

with the U.S. Department of Energy

under Contract DE-AC06-76RLO 1830

Pacific Northwest National Laboratory Richland, Washington 


\section{DISCLAIMER}

This report was prepared as an account of work sponsored by an agency of the United States Government. Neither the United States Government nor any agency thereof, nor any of their employees, make any warranty, express or implied, or assumes any legal liability or responsibility for the accuracy, completeness, or usefulness of any information, apparatus, product, or process disclosed, or represents that its use would not infringe privately owned rights. Reference herein to any specific commercial product, process, or service by trade name, trademark, manufacturer, or otherwise does not necessarily constitute or imply its endorsement, recommendation, or favoring by the United States Government or any agency thereof. The views and opinions of authors expressed herein do not necessarily state or refiect those of the United States Government or any agency thereof. 


\section{DISCLAIMER}

Portions of this document may be illegible in electronic image products. Images are produced from the best available original document. 


\section{SUMMARY}

This report, PNNL-11911 Rev. 1, was published in July 2000 and replaces PNNL-11911, which was published in September 1998. The revision corrects tissue concentration units that were reported as dry weight but were actually wet weight, and updates conclusions based on the correct reporting units.

Marine sediment remediation at the United Heckathorn Superfund Site was completed in April 1997. Water and mussel tissues were sampled in January 1998 from four stations near Lauritzen Canal in Richmond, California, for the first post-remediation monitoring of marine areas near the United Heckathorn Site. Dieldrin and DDT were analyzed in water samples, tissue samples from resident mussels, and tissue samples from transplanted mussels deployed for 4 months. Concentrations of dieldrin and total DDT in water and total DDT in tissue were compared to pre-remediation data available from the California State Mussel Watch program (tissues) and the Ecological Risk Assessment for the United Heckathorn Superfund Site (tissues and water).

Chlorinated pesticide concentrations in water samples were similar to pre-remediation levels and did not meet remediation goals. Mean dieldrin concentrations in water ranged from $0.65 \mathrm{ng} / \mathrm{L}$ to $18.1 \mathrm{ng} / \mathrm{L}$ and were higher than the remediation goal $(0.14 \mathrm{ng} / \mathrm{L})$ at all stations. Mean total DDT concentrations in water ranged from $0.65 \mathrm{ng} / \mathrm{L}$ to $103 \mathrm{ng} / \mathrm{L}$ and exceeded the remediation goal of $0.59 \mathrm{ng} / \mathrm{L}$. The highest concentrations of both pesticides were found in Lauritzen Canal, and the lowest levels were from the Richmond Inner Harbor Channel water. Unusual amounts of detritus in the water column at the time of sampling, particularly in Lauritzen Canal, could have contributed to the elevated pesticide concentrations and poor analytical precision.

Tissue samples from biomonitoring organisms (mussels) provide an indication of the longer-term integrated exposure to contaminants in the water column, which overcomes the limitations of a single-point-in-time water sample. Biomonitoring results indicated that pesticides were still bioavailable in the water column, and have not been reduced from pre-remediation levels. Total DDT and dieldrin concentrations in mussel tissues were generally higher than measured levels from pre-remediation surveys. Mean chlorinated pesticide concentrations were highest at Lauritzen Canal/End $(4,003 \mu \mathrm{g} / \mathrm{kg}$ total DDT and $232 \mu \mathrm{g} / \mathrm{kg}$ dieldrin, wet weight; mean of resident and transplant mussels), followed by Lauritzen Canal/Mouth (1335 $\mu \mathrm{g} / \mathrm{kg}$ total DDT and 
$103 \mu \mathrm{g} / \mathrm{kg}$ dieldrin, wet weight) and Santa Fe Channel/End $(435 \mu \mathrm{g} / \mathrm{kg}$ total DDT and $45.6 \mu \mathrm{g} / \mathrm{kg}$ dieldrin, wet weight).

The lowest levels were found at the Richmond Inner Harbor Channel station $(120 \mu \mathrm{g} / \mathrm{kg}$ total DDT and $8.3 \mu \mathrm{g} / \mathrm{kg}$ dieldrin, wet weight; mean of resident and transplant mussels). The relative increase above pre-remediation levels was greatest at the Richmond Inner Harbor Channel station, where post-remediation DDT concentrations were about 3 times higher than preremediation DDT concentrations.

Active dredging in the Santa Fe Channel may have contributed to the bioavailability of pesticides to mussels and the relative difference between pre- and post-remediation tissue concentrations, especially outside of Lauritzen Canal. Differences in tissue concentrations between resident and transplanted mussels were observed, but these were attributable, in part, to differences in lipid content of tissues. Either resident or transplanted mussels would be appropriate for biomonitoring in the future; both will be measured for at least one more year of the Heckathorn post-remedial monitoring program. Annual biomonitoring will continue to assess the effectiveness of remedial actions at the United Heckathorn Site. 


\section{CONTENTS}

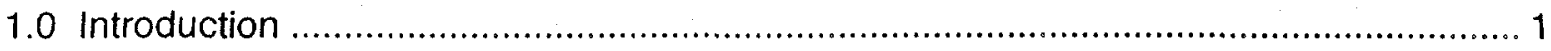

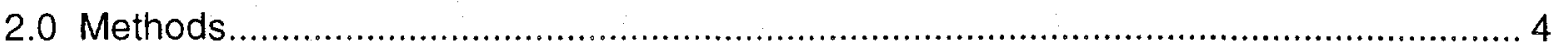

2.1 Collection and Deployment of Transplanted Mussel Stock ................................4

2.2 Tissue and Water Sample Collection and Analysis ....................................... 6

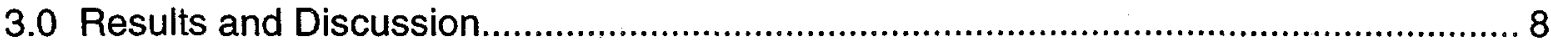

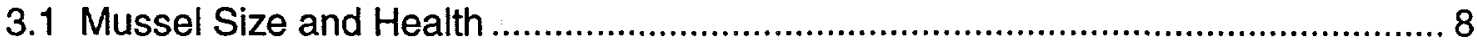

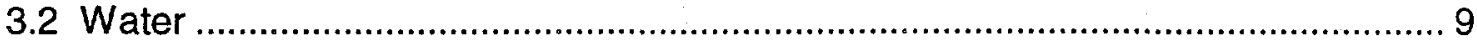

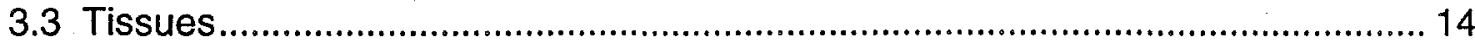

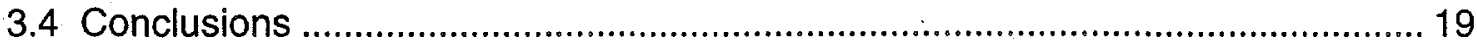

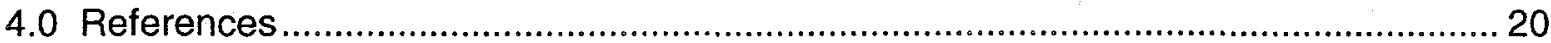

Appendix A: Field Sampling Report

Appendix B: Analytical Results for Water and Tissue Samples 


\section{FIGURES}

1.1 Location of the United Heckathorn Superfund Site, Richmond, California 2

2.1 Sampling Stations for Long-Term Post-Remediation Monitoring of the United Heckathorn Site 5

\section{TABLES}

1.1 Remediation Levels for Surface Water Specified in the Record of Decision for the United Heckathorn Superfund Site

2.1 Sampling Stations for Post-Remediation Monitoring in 1997-1998 of the United Heckathorn Site

3.1 Length and Weight Data from Mussels Collected for Tissue Samples in January 1998 for Post-Remediation Monitoring of the United Heckathorn Site 10

3.2 Concentrations of DDT and Dieldrin in Water Samples Collected in January 1998 for Post-Remedial Monitoring of the United Heckathorn Site 12

3.3 Comparison of 1998 Mean Post-Remediation Total DDT and Dieldrin in Water with Pre-Remediation and Remediation Goal Concentrations.

3.4 Concentrations of DDT and Dieldrin in Tissue Samples Collected in January 1998 for Post-Remediation Monitoring of the United Heckathorn Site

3.5 Comparison of 1998 Post-Remediation Total DDT and Dieldrin in Tissues with Pre-Remediation Concentrations ( $\mu \mathrm{g} / \mathrm{kg}$ wet weight)

3.6 Comparison of 1998 Post-Remediation Total DDT and Dieldrin in Tissues with Pre-Remediation Concentrations ( $\mu \mathrm{g} / \mathrm{kg}$ lipid weight) 


\subsection{INTRODUCTION}

The United Heckathorn Site is located in Richmond Harbor, on the east side of San Francisco Bay in Contra Costa County, California (Figure 1.1). The Site is an active marine shipping terminal operated by the Levin Richmond Terminal Corporation. The Site was listed by the U.S. Environmental Protection Agency (EPA) on its National Priorities List of Federal Superfund sites because of chemical contamination of upland and marine sediments. A Remedial Investigation of adjacent marine areas revealed widespread sediment contamination with pesticides, particularly DDT and dieldrin (White et al., 1994). Significant pesticide contamination was limited to the soft geologically recent deposits known as younger bay mud. Pesticide concentrations were highest in the Lauritzen Canal, and decreased with increasing distance from the former United Heckathorn Site, clearly indicating that Heckathorn was the source of contamination. An ecological risk assessment at the Heckathorn Site (Lee et al., 1994) reviewed data collected in 1991 and 1992 for contaminant concentrations in marine water, organisms, and sediments. This assessment revealed that DDT and dieldrin contamination, originating from the United Heckathorn Site, was actively transported to offsite areas via surface waters.

Tissue samples from mussels collected near the Lauritzen Canal have been analyzed for DDT and dieldrin in two previous studies. The Heckathorn Ecological Risk Assessment (Lee et al., 1994) analyzed tissues from native (i.e., resident) mussels collected from stations of opportunity in 1991 and 1992 in the Lauritzen Canal (ferry rudder and rope NE of ferry), the Santa Fe Channel (boat house float), and Richmond Inner Harbor Channel (red nun buoy \#16). For the California State Mussel Watch program, transplanted mussels (Mytilus californianus) were deployed at four Mussel Watch sites in or adjacent to the United Heckathorn Superfund Site (Santa Fe Channel/Mouth, Santa Fe Channel/End, Lauritzen Canal/End, and Lauritzen Canal/Mouth) (Rasmussen 1995). The State Mussel Watch program's Santa Fe Channel/Mouth site and the Heckathorn Ecological Risk Assessment's Richmond Inner Harbor Channel site were had similar locations. The pre-remediation Ecological Risk Assessment and State Mussel Watch data were the basis for comparison with the current post-remediation biomonitoring results. 


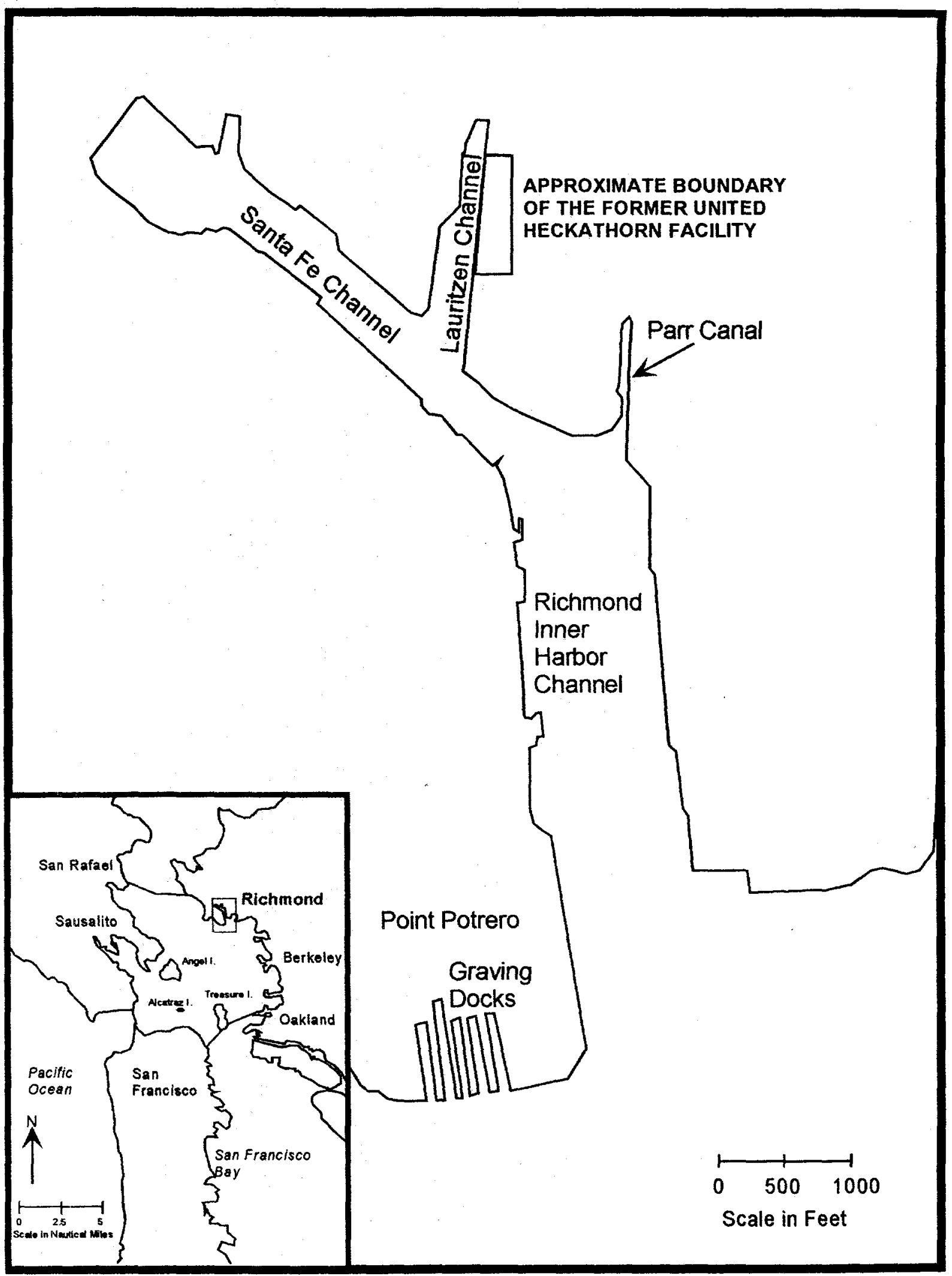

Figure 1.1. Location of the United Heckathorn Superfund Site, Richmond, California 
The final remedial actions at the Heckathorn Site outlined in the Record of Decision (ROD 1996) have the following major components:

- dredging of all soft bay mud from the Lauritzen Canal and Parr Canal, with offsite disposal of dredged material,

- placement of clean material after dredging,

- construction of a cap around the former Heckathorn facility to prevent erosion,

- a deed restriction limiting use of the property at the former Heckathorn facility location to non-residential uses,

- marine monitoring to verify the effectiveness of the remedy.

Remediation levels that would be protective of the environment and human health were established to provide benchmarks for determining the effectiveness of the remedial actions. The Feasibility Study (Lincoff et al., 1994) and the ROD reviewed federal and state environmental laws that contained Applicable or Relevant and Appropriate Requirements (ARARs) for the remedial actions. EPA marine chronic and human health water quality criteria (WQC) were identified as ARARs for surface water. Because the human health standards based on consumption of contaminated fish are lower, these were selected as remedial goals. No chemical-specific ARARs were identified as remedial goals for marine sediments or tissues at the site.

This report provides the results of the first phase of post-remediation monitoring. The purpose of the marine monitoring is to demonstrate a reduction in flux of contaminants from the United Heckathorn Superfund Site following EPA response actions, including soil removals, dredging, and cap placement at the former Heckathorn facility. The measurement endpoints for this longterm monitoring are mussels and surface waters. Remediation levels set forth in the ROD are provided in Table 1.1.

Table 1.1. Remediation Levels for Surface Water Specified in the Record of Decision for the United Heckathorn Superfund Site

\begin{tabular}{lcc}
\hline Chemical & DDT (total) $^{(\text {a) }}$ & Dieldrin \\
\hline Remediation Goal & $0.59 \mathrm{ng} / \mathrm{L}$ & $0.14 \mathrm{ng} / \mathrm{L}$ \\
\hline (a) The sum of the 4,4'- and $2,4^{\prime}$-isomers of DDT, DDD (TDE), and DDE \\
\hline
\end{tabular}




\subsection{METHODS}

Methods for collection, processing, and analysis of tissue and water samples were outlined in the Field Sampling and Analysis Plan (Battelle 1997); a brief review is provided here. All procedures for sampling, sample custody and field/lab documentation, plus other aspects of documentation, quality assurance, and sample analysis were consistent with the Quality Assurance Project Plan (QAPjP) for Remedial Investigation and Feasibility Study of Marine Sediments at the United Heckathorn Superfund Site (Battelle 1992).

The four post-remedial monitoring stations were selected to overlap stations sampled in the preremedial State Mussel Watch program (Figure 2.1). Three of the stations also overlap with locations sampled during the Ecological Risk Assessment (Lee et al., 1994). The Ecological Risk Assessment Lauritzen Canal station corresponds to Mussel Watch Station 303.3, Lauritzen Canal/End; the Ecological Risk Assessment Santa Fe Channel station corresponds to Mussel Watch Station 303.4. The Richmond Inner Harbor station for the Ecological Risk Assessment was at the navigational nun buoy (\#16), which is about $1200 \mathrm{ft}$ offshore from Richmond Inner Harbor Channel. There was no Ecological Risk Assessment sampling station that corresponded with Mussel Watch Station 303.2, Lauritzen Canal/Mouth. Mussel tissue samples were collected and analyzed in both of the pre-remedial studies, but no water samples were analyzed for the State Mussel Watch program. A more detailed description of sampling stations is provided in the Field Sampling Summary memo (Appendix A; Lincoff 1998).

\subsection{Collection and Deployment of Transplanted Mussel Stock}

California mussels ( $M$. californianus) were collected on September 3, 1997, from the north side of Bodega Head, California. This is the same area used by the California State Mussel Watch program for collection of transplant mussel stock (Gary Ichikawa, California Department of Fish and Game, personal communication). Scientists from the EPA Region 9 laboratory and Battelle Marine Sciences Laboratory (MSL) gathered mussels by hand at low tide from rocky intertidal habitat at approximately $+1 \mathrm{ft}$ to $+3 \mathrm{ft}$ mean lower low water (MLLW). Mussels were collected in nylon mesh bags and were held in coolers for transport. 


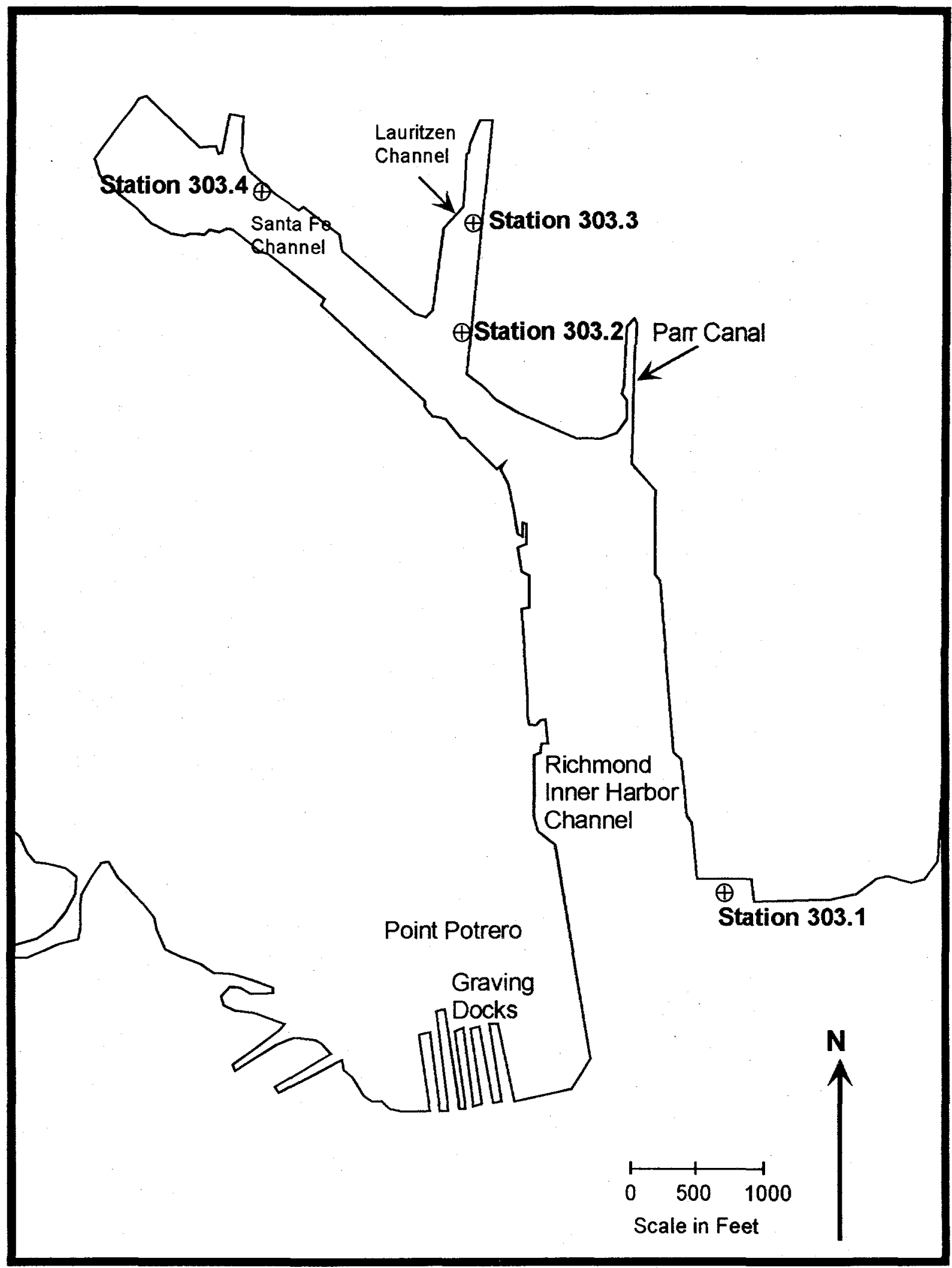

Figure 2.1. Sampling Stations for Long-Term Post-Remediation Monitoring of the United Heckathorn Site 
At the EPA Region 9 laboratory, mussels were cleaned gently to remove epiphytes, and sorted to select individuals at approximately $40 \mathrm{~mm}$ to $60 \mathrm{~mm}$ shell length. Selected mussels were placed in tubular plastic mesh bags, divided into three groups of approximately 20 mussels each, and closed with a plastic cable tie. Mesh bags with transplanted mussels were tied to nylon rope and suspended subtidally at four sampling stations. Initial collection and deployment in the field was completed on the same day, September 3 . Nylon ropes were placed inconspicuously to avoid vandalism.

\subsection{Tissue and Water Sample Collection and Analysis}

A background mussel tissue sample was prepared from the transplant mussel stock on the day of initial deployment (September 3, 1997). Approximately 45 whole mussels were placed in two layers of ashed aluminum foil, labeled, and packed in a sealed Ziploc bag. The sample was held on ice for transport to the analytical laboratory, then frozen and stored at $-20^{\circ} \mathrm{C}$ until processed with other tissue samples in January 1998.

After transplanted mussels had been deployed for 4 months, seawater, transplanted California mussels ( $M$. californianus), and resident blue mussels ( $M$. edulis) were collected for analysis. On January 6, 1998, samples were collected at Richmond Inner Harbor Channel (Station 303.1), Lauritzen Canal/End (Station 303.3), and Santa Fe Channel/End (Station 303.4) (Figure 2.1). Resident blue mussels could have been one of several subspecies or hybrids in the $M$. edulis complex that cannot be easily distinguished by the shells alone (Harbo 1997). Samples were not collected on January 6 at Lauritzen Canal/Mouth (Station 303.2) because access to the transplanted mussels at this station was blocked by pile driving equipment at the Levin Pier. Safe access for sampling at Station 303.2 was available the next day, January 7 , when samples were collected. Location coordinates presented in Table 2.1 were recorded for each station using a Global Positioning System with differential correction (dGPS). Samples were collected at low tide on a calm day with light rain. Ambient water temperature was $12^{\circ} \mathrm{C}$. Water and tissue samples were also collected for analysis by the EPA Region 9 laboratory for an interlaboratory comparison. A field sampling summary prepared by EPA Region 9 staff is provided here in Appendix A (Lincoff 1998). 
Table 2.1. Sampling Stations for Post-Remediation Monitoring in 1997-1998 of the United Heckathorn Site

\begin{tabular}{|c|c|c|c|}
\hline $\begin{array}{l}\text { Station } \\
\text { Number }\end{array}$ & Station Name & Location & Remarks \\
\hline 303.1 & $\begin{array}{l}\text { Richmond Inner Harbor } \\
\text { Channel }\end{array}$ & $\begin{array}{l}37^{\circ} 54^{\prime} 32.8^{\prime \prime} \mathrm{N} \\
122^{\circ} 21^{\prime} 34.5^{\prime \prime} \mathrm{W}\end{array}$ & $\begin{array}{l}\text { On western most wooden dolphin } \\
\text { southeast of public fishing pier }\end{array}$ \\
\hline 303.2 & $\begin{array}{l}\text { Lauritzen Canal/Mouth } \\
\text { (South) }\end{array}$ & $\begin{array}{l}37^{\circ} 55^{\prime} 12.6^{\prime \prime} \mathrm{N} \\
122^{\circ} 22^{\prime} 01.2^{\prime \prime} \mathrm{W}\end{array}$ & $\begin{array}{l}\text { On east side directly across from } \\
\text { concrete embankment/corner on } \\
\text { western side }\end{array}$ \\
\hline 303.3 & $\begin{array}{l}\text { Lauritzen Canal/End } \\
\text { (North) }\end{array}$ & $\begin{array}{l}37^{\circ} 55^{\prime} 22.5^{\prime \prime} \mathrm{N} \\
122^{\circ} 21^{\prime} 59.9^{\prime \prime} \mathrm{W}\end{array}$ & $\begin{array}{l}\text { On east side, at small wooden } \\
\text { pier }\end{array}$ \\
\hline 303.4 & Santa Fe Channel/End & $\begin{array}{l}37^{\circ} 55^{\prime} 21.53^{\prime \prime} \mathrm{N} \\
122^{\circ} 21^{\prime} 18.37^{\prime \prime} \mathrm{W}\end{array}$ & $\begin{array}{l}\text { At west end of boat shed on } \\
\text { north side, east of small boat fuel } \\
\text { dock }\end{array}$ \\
\hline
\end{tabular}

Surface water samples were collected approximately $0.3 \mathrm{~m}$ below the water surface. To collect a sample, a bottle was submerged, the cap was removed under water to fill, and the cap replaced before the bottle was lifted. At each station, three 2-L water samples were collected for analysis by Battelle MSL. Additional water samples were collected for quality control (i.e., matrix spike, matrix spike duplicate, and blind duplicate water samples). Water samples were chilled to and held at $4^{\circ} \mathrm{C}$ until extracted. Water salinity was not recorded in the field but was measured in samples at the analytical laboratory. Salinity of all water samples checked pre-extraction was $28 \%$. Samples from Richmond Inner Harbor Channel and Lauritzen Canal/End were extracted before salinity was measured, and salinity in post-extraction water ranged from $32.5 \%$ o to $34 \%$. Therefore, extraction seems to have altered the water salinity or refractory index to produce anomalous salinity values. Salinity of all water samples was assumed to have been $28 \%$.

Resident mussels were collected from approximately $+1 \mathrm{ft}$ MLLW at Richmond Inner Harbor Channel, Lauritzen Canal/Mouth, and Lauritzen Canal/End. Transplanted mussels had been deployed at approximately $-3 \mathrm{ft} \mathrm{MLLW} \mathrm{at} \mathrm{Richmond} \mathrm{Inner} \mathrm{Harbor} \mathrm{Channel} \mathrm{and} \mathrm{Lauritzen}$ Canal/Mouth, and at $-6 \mathrm{ft}$ MLLW at Lauritzen Canal/End. At Santa Fe Channel/End, resident and transplanted mussels were attached to a floating dock, under which resident mussels were within $1 \mathrm{ft}$ of the water surface and transplanted mussels were approximately $8 \mathrm{ft}$ below the water surface. Mussels were cleaned gently in the field and packaged whole in ashed foil and 
plastic bags, as described above. Mussel samples were held frozen at $-20^{\circ} \mathrm{C}$ until soft tissue samples were processed for analysis. To prepare tissue samples, mussels were partially thawed, the valve or shell length was measured, byssus threads were cut from the tissue, and soft tissues were transferred to a sample jar. Sand and mud on the soft tissue was rinsed off with deionized water. Each tissue sample was comprised of between 35 and 45 individual mussels. The total wet weight of each tissue sample was recorded. Tissue samples were refrozen until extracted.

Chemical analyses followed methods described in the QAPJP (Battelle 1992). Water and tissues samples were analyzed for chlorinated pesticides. Tissue samples were also analyzed for total lipids. Total DDT was calculated as the sum of detected concentrations for six DDT compounds: 2,4-DDE, 4,4-DDE, 2,4-DDD, 4,4-DDD, 2,4-DDT, and 4,4-DDT. The detection limit was not used in calculation of total DDT. Total DDT, or sum of DDTs, was calculated in the same manner in the California State Mussel Watch program (Rasmussen 1995) and the Ecological Risk Assessment for the United Heckathorn Superfund Site (Lee et al., 1994).

\subsection{RESULTS AND DISCUSSION}

This section presents the results of physical measurements to assess the size and health of transplanted and resident mussels, and the results of pesticide analysis of water and mussel tissue. All extractions and analyses were conducted within target holding times. Complete data tables with results for water and tissue analyses, including quality control data, are provided in Appendix B. The current 1998 post-remedial water monitoring data are compared with preremedial data from the Ecological Risk Assessment and with the remedial goals for the site. The current post-remedial tissue monitoring data are compared with pre-remedial tissue concentrations from the State Mussel Watch program and the Ecological Risk Assessment.

\subsection{Mussel Size and Health}

Mussels collected for tissue samples were of similar size, although some individuals exceeded the preferred size range of 40 to $65 \mathrm{~mm}$ (combined ranges from Rasmussen 1995 and Lee et al., 1994). Raw data for shell length measurements and mean wet weight per mussel is provided in Table 3.1. Shell length of transplanted California mussels in the background sample ranged from $45 \mathrm{~mm}$ to $62 \mathrm{~mm}$ (mean $=52 \mathrm{~mm}$ ). Four months later, California mussels transplanted to the study site were between $44 \mathrm{~mm}$ and $66 \mathrm{~mm}$ long (mean $=54 \mathrm{~mm}$ ). Resident mussels collected in January 1998 ranged from $40 \mathrm{~mm}$ to $76 \mathrm{~mm}$ shell length (mean $=56 \mathrm{~mm}$ ). 
The overall mean weight of mussels was calculated as the total wet weight of the tissue sample divided by the number of individuals per sample. Mean weights of mussels were $5.28 \mathrm{~g}$ for the background sample, and $5.81 \mathrm{~g}$ and $5.84 \mathrm{~g}$ for transplanted and resident mussels in January 1998, respectively. These data showed that transplanted California mussels grew in both length and weight during the four-month deployment period.

The lipid content was similar for the background tissue sample ( $9.60 \%$ dry weight) and transplanted mussel samples collected in January 1998 (range of $8.71 \%$ to $10.1 \%$, mean of $9.60 \%$ dry weight). This indicated that the deployed transplanted mussels were in good health and that bioaccumulation of contaminants was not likely to have been compromised by poor health, poor water quality, or limited food availability for the deployed organisms. Lipid content of resident mussels was similar to but slightly more variable than that of transplanted mussels, ranging from $6.26 \%$ to $10.2 \%$ dry weight (mean of $8.99 \%$ ). It should be noted that tissue lipid content is not a definitive indicator of organism health because lipid content in bivalves can vary significantly depending on the availability of food and the bivalve's reproductive cycle.

\subsection{Water}

Triplicate water samples were collected at each site on the same day. These samples provided a "snapshot" of water column concentrations of DDT compounds and dieldrin, but they provided no information about the temporal variability or vertical stratification of these contaminants in the water column or the variability in water column concentrations to which biomonitoring organisms had been exposed. The absence of evaluation of temporal variability should be considered when these data are compared with results from earlier studies. Pre-remediation water samples collected for the Ecological Risk Assessment (Lee et al., 1994) provided more data on temporal variability because samples were taken over three successive days at two different sampling periods, approximately four months apart.

Water samples were extracted with solvent, and solvent extracts were concentrated to $0.2-\mathrm{mL}$ volume for an overall enhancement factor of approximately 10,000 in an attempt to achieve detection levels below the remediation goals. Recoveries of surrogate compounds were low in 6 of 15 water samples and 4 of 7 quality control samples because of the additional drying steps required to remove residual water, potential loss of portions of samples, and extra evaporation steps necessary to achieve a low final sample volume. All data were corrected using the 
Table 3.1. Length and Weight Data from Mussels Collected for Tissue Samples in January 1998 for Post-Remediation Monitoring of the United Heckathorn Site

\begin{tabular}{|c|c|c|c|c|c|c|c|c|c|}
\hline \multirow[b]{3}{*}{ Mussel \# } & \multicolumn{9}{|c|}{ Shell Length $(\mathrm{cm})$} \\
\hline & \multicolumn{2}{|c|}{303.1} & \multicolumn{2}{|c|}{303.2} & \multicolumn{2}{|c|}{303.3} & \multicolumn{2}{|c|}{303.4} & \multirow[b]{2}{*}{ Background } \\
\hline & Transplant & Resident & Transplant & Resident & Transplant & Resident & Transplant & Resident & \\
\hline 1 & 5.20 & 5.18 & 5.99 & 6.86 & 5.77 & 6.75 & 4.71 & 6.49 & 5.50 \\
\hline 2 & 6.02 & 6.23 & 5.05 & 6.90 & 5.13 & 6.00 & 5.26 & 6.12 & 5.48 \\
\hline 3 & 5.20 & 5.04 & 5.52 & 7.55 & 5.49 & 5.96 & 4.99 & 6.41 & 4.85 \\
\hline 4 & 5.15 & 5.85 & 4.81 & 6.85 & 5.39 & 4.53 & 4.40 & 5.69 & 6.10 \\
\hline 6 & 5.52 & 6.41 & 5.43 & 6.50 & 5.16 & 4.65 & 5.55 & 5.90 & 5.53 \\
\hline 7 & 5.35 & 5.49 & 5.07 & 6.74 & 5.08 & 4.66 & 4.86 & 5.89 & 5.67 \\
\hline 8 & 5.80 & 5.78 & 6.29 & 5.91 & 5.79 & 5.19 & 4.85 & 5.76 & 5.26 \\
\hline 9 & 5.47 & 4.90 & 4.80 & 6.11 & 5.66 & 5.80 & 5.94 & 5.88 & 5.81 \\
\hline 10 & 5.38 & 5.65 & 5.26 & 6.49 & 5.50 & 4.65 & 5.40 & 6.03 & 4.73 \\
\hline 11 & 5.56 & 5.95 & 5.27 & 4.98 & 4.96 & 6.92 & 5.17 & 5.16 & 5.61 \\
\hline 12 & 5.01 & 5.85 & 6.40 & 5.63 & 5.25 & 4.71 & 6.05 & 5.21 & 4.84 \\
\hline 14 & 4.98 & 5.22 & 5.17 & 4.59 & 5.98 & 5.52 & 5.05 & 5.55 & 5.15 \\
\hline 15 & 4.72 & 5.51 & 5.03 & 5.68 & 6.58 & 4.81 & 5.12 & 6.32 & 5.10 \\
\hline 16 & 5.68 & 6.90 & 4.86 & 7.29 & 5.76 & 4.25 & 5.04 & 5.87 & 4.91 \\
\hline 17 & 5.06 & 5.51 & 5.01 & 6.21 & 4.70 & 4.94 & 5.47 & 6.17 & 5.65 \\
\hline 18 & 6.07 & 6.17 & 4.89 & 5.35 & 5.94 & 6.50 & 6.08 & 5.68 & 4.92 \\
\hline 19 & 4.89 & 5.15 & 6.24 & 6.21 & 5.53 & 5.50 & 5.27 & 5.75 & 5.14 \\
\hline 20 & 4.92 & 4.75 & 5.00 & 6.32 & 5.90 & 5.42 & 5.13 & 5.49 & 4.68 \\
\hline 21 & 5.23 & 5.79 & 5.05 & 5.97 & 5.15 & 6.29 & 5.76 & 4.55 & 5.02 \\
\hline 22 & 6.57 & 6.75 & 5.00 & 5.86 & 4.74 & 6.54 & 6.00 & 5.22 & 5.08 \\
\hline 23 & 5.33 & 6.95 & 5.01 & 5.00 & 5.77 & 6.59 & 4.84 & 6.40 & 5.62 \\
\hline 24 & 4.94 & 6.01 & 6.00 & 5.49 & 5.65 & 6.61 & 5.87 & 4.98 & 4.78 \\
\hline 25 & 5.69 & 5.15 & 4.92 & 6.00 & 5.67 & 6.38 & 5.09 & 5.95 & 5.23 \\
\hline 26 & 5.05 & 5.07 & 5.44 & 6.14 & 6.12 & 5.63 & 5.91 & 6.25 & 5.47 \\
\hline 27 & 5.72 & 6.56 & 6.23 & 6.14 & 5.17 & 4.94 & 4.84 & 6.32 & 5.09 \\
\hline 28 & 5.50 & 6.01 & 4.82 & 5.88 & 5.80 & 4.94 & 5.48 & 4.81 & 5.51 \\
\hline
\end{tabular}


Table 3.1. (contd)

\begin{tabular}{|c|c|c|c|c|c|c|c|c|c|}
\hline \multirow[b]{3}{*}{ Mussel \# } & \multicolumn{9}{|c|}{ Shell Length $(\mathrm{cm})$} \\
\hline & \multicolumn{2}{|c|}{303.1} & \multicolumn{2}{|c|}{303.2} & \multicolumn{2}{|c|}{303.3} & \multicolumn{2}{|c|}{303.4} & \multirow[b]{2}{*}{ Background } \\
\hline & Transplant & Resident & Transplant & Resident & Transplant & Resident & Transplant & Resident & \\
\hline 29 & 5.38 & 4.18 & 6.36 & 5.66 & 6.28 & 4.28 & 5.11 & 5.26 & 5.35 \\
\hline 30 & 5.20 & 6.49 & 4.72 & 5.72 & 5.78 & 4.65 & 5.20 & 6.20 & 5.12 \\
\hline 31 & 5.36 & 4.13 & 4.65 & 6.32 & 5.26 & 4.26 & 5.59 & 5.81 & 4.97 \\
\hline 32 & 5.36 & 5.05 & 5.76 & 6.12 & 5.18 & 5.14 & 5.55 & 5.99 & 5.66 \\
\hline 33 & 5.31 & 5.05 & 5.56 & 5.21 & 5.50 & 4.86 & 5.41 & 5.10 & 6.15 \\
\hline 34 & 5.65 & 4.58 & 6.05 & 5.57 & 5.39 & 5.53 & 4.88 & 6.27 & 5.04 \\
\hline 35 & 5.07 & 6.33 & 6.05 & 6.18 & 6.31 & 6.44 & 5.54 & 5.31 & 5.15 \\
\hline 36 & & 6.16 & 5.11 & 5.75 & 5.72 & 5.62 & 5.93 & 5.38 & 4.68 \\
\hline 37 & & 5.87 & 5.57 & 5.19 & 6.14 & 4.91 & 6.33 & 5.37 & 4.68 \\
\hline 38 & & 5.11 & 5.61 & 5.45 & 5.01 & 4.00 & 6.03 & 5.22 & 4.85 \\
\hline 39 & & 5.30 & 4.87 & 5.53 & 5.42 & 5.12 & 5.26 & 5.05 & 5.47 \\
\hline 40 & & 5.94 & 5.61 & 6.25 & 5.76 & 4.65 & 4.90 & 5.98 & 5.04 \\
\hline 41 & & 5.88 & 4.93 & 5.22 & 6.29 & 4.37 & 5.18 & 4.90 & 4.66 \\
\hline 42 & & 6.91 & 5.86 & 6.05 & 5.41 & 5.77 & 4.80 & 6.31 & 4.95 \\
\hline 43 & & 5.78 & 5.07 & 5.71 & 5.41 & 4.53 & & 5.36 & 5.21 \\
\hline 44 & & 5.48 & 5.35 & 5.57 & 5.62 & & & 4.99 & \\
\hline 45 & & 5.34 & 4.59 & 4.74 & 6.04 & & & 4.77 & \\
\hline minimum length $(\mathrm{cm})$ & 4.72 & 4.13 & 4.58 & 4.59 & 4.70 & 4.00 & 4.40 & 4.55 & 4.50 \\
\hline maximum length $(\mathrm{cm})$ & 6.57 & 6.95 & 6.40 & 7.55 & 6.58 & 6.92 & 6.33 & 6.41 & 6.15 \\
\hline mean length $(\mathrm{cm})$ & 5.37 & 5.66 & 5.32 & 5.91 & 5.59 & 5.27 & 5.37 & 5.60 & 5.18 \\
\hline $\begin{array}{l}\text { mean weight per } \\
\text { mussel (g wet) }\end{array}$ & 5.67 & 5.92 & 5.37 & 7.69 & 7.01 & 4.35 & 5.20 & 5.40 & 5.28 \\
\hline mean length $(\mathrm{cm})$ & & background & 5.18 & resident & 5.61 & transplants & 5.41 & & \\
\hline mean weight ( $g$ wet) & & background & 5.28 & resident & 5.84 & transplants & 5.81 & & \\
\hline
\end{tabular}


PCB 198 surrogate percent recovery. The achieved detection limits in water samples ranged from $0.01 \mathrm{ng} / \mathrm{L}$ to $0.11 \mathrm{ng} / \mathrm{L}$ for the six DDT compounds. Recovery of one of two DDT matrix spikes was $129 \%$, slightly exceeding the quality control limits of $40 \%-120 \%$. In the method blank, $0.11 \mathrm{ng} / \mathrm{L} \mathrm{DDE}$ was detected; samples with $<5 \mathrm{X}$ the blank concentration are flagged with a "B". Replicate precision was generally poor for the cleanest station where levels were low and for the most contaminated station where organic detritus could have been a contributing factor. Given these quality control concerns, the results of water analyses should be considered estimates.

Concentrations of DDT and dieldrin measured in 1998 post-remedial water samples are shown in Table 3.2. Water column concentrations of total DDT and dieldrin were similar in the 19911992 pre-remediation and 1998 post-remediation studies (Table 3.3), except at Station 303.3 Lauritzen Canal/End. Total DDT was higher at Lauritzen Canal/End in post-remediation water samples (80 ng/L to $138 \mathrm{ng} / \mathrm{L}$, mean $103 \mathrm{ng} / \mathrm{L}$ ) than in pre-remediation water samples (22 $\mathrm{ng} / \mathrm{L}$ to $68 \mathrm{ng} / \mathrm{L}$ total DDT, mean $50 \mathrm{ng} / \mathrm{L})$.

Table 3.2. Concentrations of DDT and Dieldrin in Water Samples Collected in January 1998 for Post-Remedial Monitoring of the United Heckathorn Site

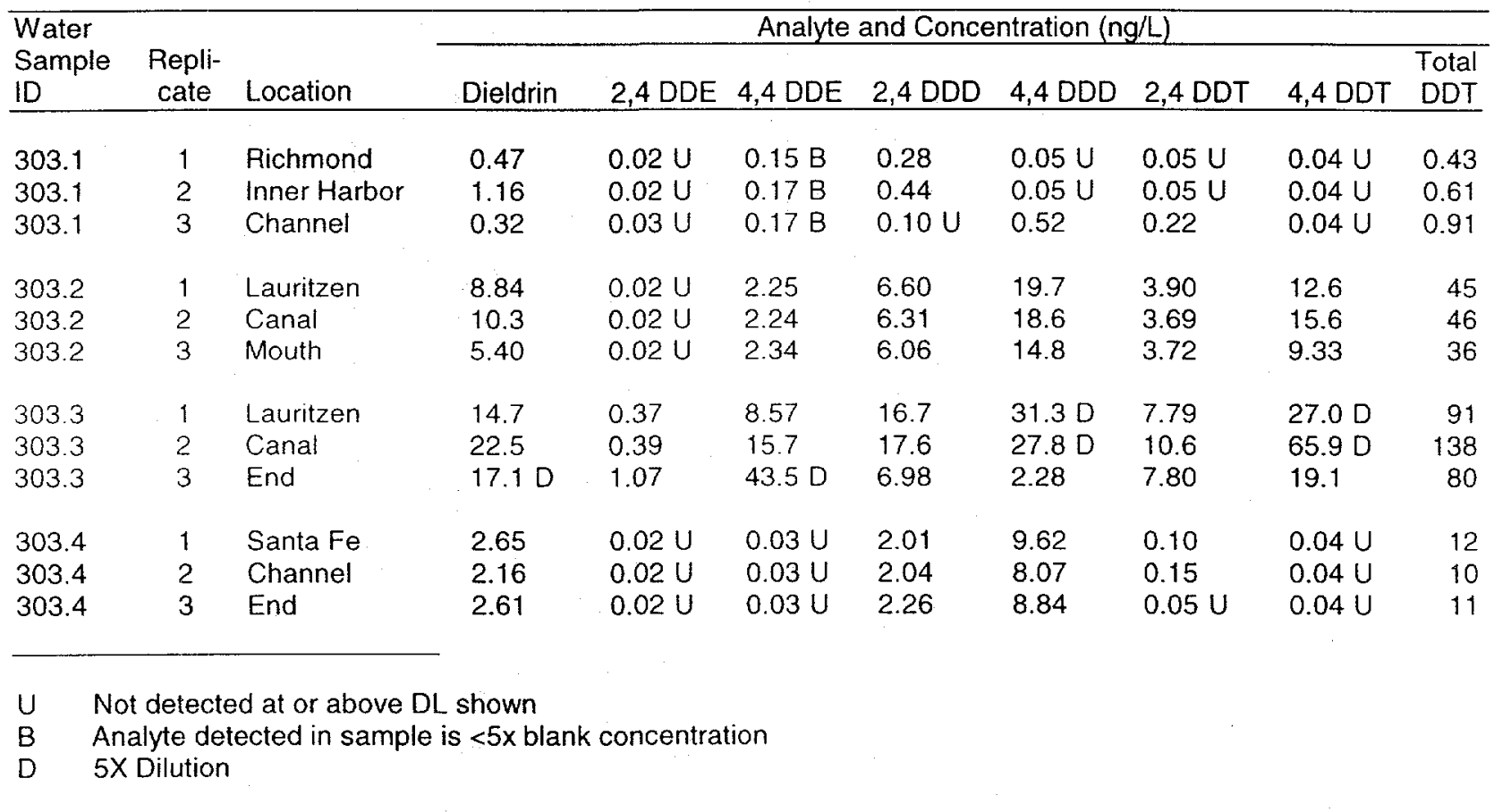


Table 3.3. Comparison of 1998 Mean Post-Remediation Total DDT and Dieldrin in Water with Pre-Remediation and Remediation Goal Concentrations (all concentrations $\mathrm{ng} / \mathrm{L}$ )

\begin{tabular}{|c|c|c|c|c|c|c|c|}
\hline \multirow{2}{*}{$\begin{array}{l}\text { Water } \\
\text { Sample ID }\end{array}$} & \multirow[b]{2}{*}{ Location } & \multicolumn{2}{|c|}{1998 Post-Remediation } & \multicolumn{2}{|c|}{ Remediation Goals } & \multicolumn{2}{|c|}{ Pre-Remediation $^{(2)}$} \\
\hline & & Total DDT & Dieldrin & Total DDT & Dieldrin & Total DDT & Dieldrin \\
\hline 303.1 & $\begin{array}{l}\text { Richmond Inner } \\
\text { Harbor Channel }\end{array}$ & 0.65 & 0.65 & 0.59 & 0.14 & 1 & $<1$ \\
\hline 303.2 & Lauritzen Canal Mouth & 42.6 & 8.18 & 0.59 & 0.14 & no sample & no sample \\
\hline 303.3 & Lauritzen Canal End & 103 & 18.1 & 0.59 & 0.14 & 50 & 18 \\
\hline 303.4 & Santa Fe Channel End & 11.0 & 2.47 & 0.59 & 0.14 & 8.6 & 1.8 \\
\hline $\begin{array}{l}\text { (a) Pre-r } \\
\text { for th }\end{array}$ & iation water concent & is av & f sample & ected ir & & & 1992 \\
\hline
\end{tabular}

As stated above, post-remediation water samples represent contaminant concentrations at a single point in time. It is impossible to determine from these data if the high levels of DDT in this post-remediation study represent a persistent condition or were a temporary event, perhaps caused by suspension of sediment from the nearby pile driving activity. In addition, an organic surface scum and detritus in the water column at the time of sampling in 1998, particularly at Lauritzen Canal/End (Station 303.3), could have contributed to elevated pesticide levels and greater field replicate variability.

Water concentrations of dieldrin and total DDT were well above remediation goals in all water samples, with one exception (Table 3.3); total DDT in water from Richmond Inner Harbor Channel was detected at levels near the remediation goal of $0.59 \mathrm{ng} / \mathrm{L}$. Triplicate water samples at this station ranged from $0.43 \mathrm{ng} / \mathrm{L}$ to $0.91 \mathrm{ng} / \mathrm{L}$ total DDT, with a mean of $0.65 \mathrm{ng} / \mathrm{L}$. Dieldrin in water from Richmond Inner Harbor Channel, however, was approximately 5 times higher than the remediation goal $(0.14 \mathrm{ng} / \mathrm{L})$. The most elevated contaminant concentrations were found in Lauritzen Canal water, where total DDT levels were between 72 times (Lauritzen Canal/Mouth) and 175 times (Lauritzen Canal/End) greater than the remediation goal. Dieldrin levels at Lauritzen Canal stations were 58 times and 129 times higher than the remediation goal. At the Santa Fe Channel/End, both total DDT and dieldrin were approximately 18 times higher than remediation goals. 


\subsection{Tissues}

Tissue samples from biomonitoring organisms provide a time-integrated indication of contaminant concentrations in the water column. These values, therefore, overcome the limitations associated with sampling water on a single day. For tissue sample analysis, all quality control requirements were met. Achieved detection limits ranged from $0.15 \mu \mathrm{g} / \mathrm{kg}$ to $0.52 \mu \mathrm{g} / \mathrm{kg}$ wet weight. The background tissue sample had $1.05 \mu \mathrm{g} / \mathrm{kg}$ total DDT and $0.66 \mu \mathrm{g} / \mathrm{kg}$ dieldrin (wet weight). Results of tissue analyses (in wet weight) from transplanted and resident mussels are provided in Table 3.4 .

The 1998 post-remediation data are compared with pre-remediation data in Table 3.5. Postremediation levels of total DDT were lowest at the Richmond Inner Harbor Channel station, at $127 \mu \mathrm{g} / \mathrm{kg}$ in resident mussels and $113 \mu \mathrm{g} / \mathrm{kg}$ in transplanted mussels. At the Santa Fe Channel/End station, total DDT was $256 \mu \mathrm{g} / \mathrm{kg}$ in resident mussels and $613 \mu \mathrm{g} / \mathrm{kg}$ transplanted mussels. At the Lauritzen Canal/Mouth, total DDT was $1222 \mu \mathrm{g} / \mathrm{kg}$ in resident and $1448 \mu \mathrm{g} / \mathrm{kg}$ in transplanted mussels. The highest levels were found in mussels from Lauritzen Canal/End, in which total DDT was $4504 \mu \mathrm{g} / \mathrm{kg}$ in resident and $3502 \mu \mathrm{g} / \mathrm{kg}$ in transplanted mussels. Trends for dieldrin in mussel tissues were similar, with the highest levels at Lauritzen Canal/Mouth and Lauritzen Canal $/$ End (103 $\mu \mathrm{g} / \mathrm{kg}$ and $232 \mu \mathrm{g} / \mathrm{kg}$ dieldrin; mean of transplanted and resident mussels, respectively) and the lowest levels at the Richmond Inner Harbor Channel station (mean of $8.3 \mu \mathrm{g} / \mathrm{kg}$ dieldrin).

Tissue burdens from the Lauritzen Canal stations in this first post-remediation survey remained elevated, at higher levels than pre-remediation tissue burdens (Table 3.5). Resident mussels within Lauritzen Canal were exposed to suspended sediment during remediation, but the high levels in the transplanted mussels indicated that DDT was bioavailable in the 9 months following remediation as well. In Lauritzen Canal/End mussels, the average post-remediation DDT burden was 1.4 times higher than the pre-remediation (Ecological Risk Assessment) DDT burden. Tissue burdens in stations outside Lauritzen Canal showed an even higher relative difference between post- and pre-remediation levels, with post-remediation Richmond Harbor mussels containing about 3 times as much total DDT as pre-remediation mussels from the same location (Table 3.5). Richmond Harbor Channel and Santa Fe Channel were deepened between September 1997 and August 1998; mussels at all of the monitoring stations would have been exposed to suspended material during this operation. 
Table 3.6. Comparison of Lipid-Normalized 1998 Post-Remediation Total DDT and Dieldrin in Tissues with Pre-Remediation Concentrations ( $\mu \mathrm{g} / \mathrm{kg}$ lipid weight)

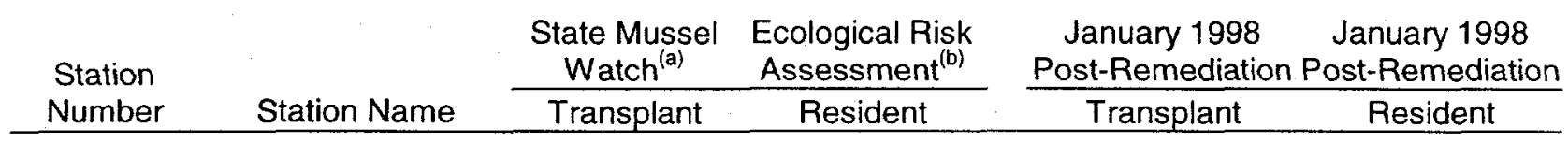

\section{Total DDT $(\mu \mathrm{g} / \mathrm{kg}$ lipid weight)}

$\begin{array}{cccccc}303.1 & \begin{array}{c}\text { Richmond Inner } \\ \text { Harbor Channel } \\ \text { Lauritzen }\end{array} & 9,215^{(\mathrm{c})} & 3,275 & 9,961 & 12,313 \\ 303.2 & \begin{array}{c}\text { Canal/Mouth } \\ 303.3\end{array} & 78,481^{(\mathrm{d})} & - & 134,247 & 134,633 \\ & \text { Lauritzen Canal/End } & \begin{array}{l}583,819^{(\mathrm{d})} \\ 380,361^{(\mathrm{c})}\end{array} & 250,411 & 368,816 & 427,423 \\ 303.4 & \begin{array}{c}\text { Santa Fe } \\ \text { Channel/End }\end{array} & 47,283^{(\mathrm{c})} & 21,919 & 51,016 & 45,695\end{array}$

Dieldrin ( $\mu \mathrm{g} / \mathrm{kg}$ lipid weight)

\begin{tabular}{|c|c|c|c|c|c|}
\hline 303.1 & $\begin{array}{l}\text { Richmond Inner } \\
\text { Harbor Channel }\end{array}$ & $1,507^{(\mathrm{c})}$ & 322 & 988 & 525 \\
\hline 303.2 & $\begin{array}{c}\text { Lauritzen } \\
\text { Canal/Mouth }\end{array}$ & $10,861^{(d)}$ & -- & 15,293 & 4,439 \\
\hline 303.3 & Lauritzen Canal/End & $\begin{array}{l}69,272^{(d)} \\
27,778^{(c)}\end{array}$ & 8,590 & 29,387 & 17,463 \\
\hline 303.4 & $\begin{array}{c}\text { Santa Fe } \\
\text { Channel/End }\end{array}$ & $4,167^{(\mathrm{c})}$ & 1,126 & 6,914 & 1,462 \\
\hline
\end{tabular}

(a) Most recent data available from State Mussel Watch program, transplanted California mussels (Rasmussen 1995).

(b) Average concentration in resident mussel tissue from samples collected in October 1991 and February 1992 (Lee et al., 1994).

(c) State Mussel Watch program sample from March 1991 (Rasmussen 1995).

(d) State Mussel Watch program sample from January 1988 (Rasmussen 1995).

1998, relative to pre-remediation concentrations. Lipid-normalized tissue values for Santa $\mathrm{Fe}$ and Richmond Inner Harbor Channels showed slight increases in DDT and dieldrin relative to pre-remediation concentrations. Differences in lipid content did not account for the difference in dieldrin concentration observed between transplant and resident mussels: lipid-normalized 
dieldrin concentrations were 1.7 to 4.7 times higher in transplanted mussels than those in resident mussels (Table 3.6).

Either transplanted or resident mussels appear to be acceptable for biomonitoring at the study site, but the differences between them should be monitored for at least one more year. Potential differences in total body burdens may have arisen from a variety of factors, including the use of different species, lipid content of tissues, duration of exposure, and height in the water column. Transplanted mussels were $M$. californianus that had negligible initial DDT contamination and that were exposed for a known time period at the study site (i.e., 4 months). Resident mussels were adult $M$. edulis that occur naturally at the study site, selected at approximately $40 \mathrm{~mm}$ to $60 \mathrm{~mm}$ shell length, that were likely to have been present before remediation had been completed. At all stations except Santa Fe Channel/End, the relative percent difference (RPD; difference/mean $\times 100$ ) in total DDT between transplanted and resident tissue burdens in wet weight was $12 \%$ to $25 \%$. At the Santa Fe Channel/End station, the RPD between resident and transplant tissue burdens was $82 \%$ (wet weight basis). Lipid-normalization reduced the apparent variability in tissue DDT burdens: the RPDs for total DDT on a lipid-normalized basis were between $0 \%$ and $21 \%$ at Richmond Inner Harbor and both Lauritzen Canal stations, and $11 \%$ at Santa Fe Channel/End. Thus, a portion of the difference between resident and transplanted mussels was attributable to differences in lipid content of tissues. Neither resident nor transplanted mussels were consistently higher or lower in total DDT concentrations.

For dieldrin, RPDs were higher than those for total DDT and ranged from $41 \%$ to $164 \%$ for wet weight data and from $51 \%$ to $130 \%$ for lipid-normalized data. Again, the biggest difference was observed at the Santa Fe Channel/End station. Dieldrin levels in resident mussels were consistently much lower than those in transplanted mussels (Tables 3.4, 3.5, and 3.6). Analysis of a background tissue sample confirmed that transplanted mussels did not contain significant levels of dieldrin at deployment. Therefore, it appears that transplanted mussels were exposed to higher dieldrin concentrations or were more effective in accumulating dieldrin than were resident mussels. This effect was not demonstrated for total DDT. Observed differences between transplanted and resident mussels also may have been attributable, in part, to height in the water column. At the Santa Fe Channel/End station, where the most significant difference in DDT burden between transplanted and resident mussels was found, mussels were attached to a floating boathouse. Resident and transplanted mussels were consistently at $-0.5 \mathrm{ft}$ and $-8 \mathrm{ft}$ below the water surface, respectively. The transplanted mussels were deployed at this depth to 
reduce the probability of vandalism. Transplanted mussels at all other sites were attached to firm substrate at a fixed position. It is not known if attachment to a floating structure at different depths in the water column contributed to differences in bioaccumulation. In the future, it might be better to deploy mussels nearer to resident mussels and at a fixed height in the water column. In addition, sampling resident and transplanted mussels in early 1999 is recommended to provide more data for evaluation of differences in dieldrin uptake by the two types of mussels.

\subsection{Conclusions}

Results from the first post-remediation monitoring indicated that chlorinated pesticides remained in the Lauritzen Canal and in the semi-enclosed waters nearby. Remediation goals for total DDT and dieldrin in water have not yet been achieved for the study site. Biomonitoring indicated that the total DDT concentration in the water was not reduced, and in fact appeared to have increased somewhat, from pre-remediation levels in the first 9 months following remediation. As noted in the Field Sampling Summary, dredging for a deepening project in the Santa Fe and Richmond Inner Harbor Channels was ongoing since the fall of 1997, throughout most if not all of the time that transplanted mussels were deployed. Dredging operations started in the Santa Fe Channel, near Station 303.4, and was active near Brooks Island and Point Potrero, near Station 303.1, when samples were collected. Dredging activity was likely to have resuspended sediment containing DDT and dieldrin and may have influenced the water column concentration and potential exposure of mussels to these contaminants of concern. Unusual amounts of detritus in the water could also have contributed to elevated surface water measurements that are inconsistent with the mussel tissue results. Further biomonitoring will be important to determine if these data are representative of long-term bioavailability of pesticides from the Lauritzen Canal sediments. 


\subsection{REFERENCES}

Battelle. 1992. Quality Assurance Project Plan for Remedial Investigation and Feasibility Study of Marine Sediments at the United Heckathorn Superfund Site. QA Plan EES-80, Rev. 0. Battelle Marine Sciences Laboratory, Sequim, Washington.

Battelle. 1997. Field Sampling and Analysis Plan for Long-Term Post-Remediation Monitoring at the United Heckathorn Superfund Site. Prepared for U.S. Environmental Protection Agency, Region 9, San Francisco, California. Battelle Marine Sciences Laboratory, Sequim, Washington, April 22, 1997.

Harbo, R.M. 1997. Shells and Shellfish of the Pacific Northwest: A Field Guide. Harbour Publishing, Nadeira Park, BC, Canada.

Lee II, H., A. Lincoff, B. L. Boese, F. A. Cole, S. P. Ferrara, J. O. Lamberson, R. J. Ozretich, R. C. Randall, K. R. Rukavina, D. W. Schults, K. A. Sercu, D. T. Specht, R. C. Swartz, and D. R. Young. 1994. Ecological Risk Assessment of the Marine Sediments at the United Heckathorn Superfund Site. U. S. EPA, ERL-N: N269. Final Report to Region IX; Pacific Ecosystems Branch, ERL-N, U.S. EPA, Newport, Oregon.

Lincoff, A.H., G.P. Costan, M.S. Montgomery, and P.J. White. 1994. Feasibility Study for the United Heckathorn Superfund Site Richmond, California. PNL-9991/UC-600. Prepared for the U.S. Environmental Protection Agency. Pacific Northwest Laboratory, Richland, Washington.

Lincoff, A. 1998. Field Sampling Summary for Mussels and Surface Water at the United Heckathorn Site I Richmond, California, Conducted 1/6 - 1/7/98. U.S. Environmental Protection Agency Region 9 Laboratory, Richmond, California.

Rasmussen, D. 1995. State Mussel Watch Program 1987-1993 Data Report. Report 94-1WQ. State Water Resources Control Board, California Environmental Protection Agency.

ROD (Record of Decision) 1996. United Heckathorn Superfund Site, Richmond, California. EPA ID\# CAD981436363.

White, P. J., N. P. Kohn, W. W. Gardiner, and J. Q. Word. 1994. The Remedial Investigation of Marine Sediment at the United Heckathorn Superfund Site. PNL-9383. Prepared for the U.S. Environmental Protection Agency by Battelle/Marine Sciences Laboratory, Sequim Washington; published by Pacific Northwest Laboratory, Richland, Washington. 
APPENDIX A

FIELD SUMMARY REPORT 


\section{UNITED STATES ENVIRONMENTAL PROTECTION AGENCY \\ REGION IX LABORATORY \\ 1337 S. 46TH STREET \\ BLDG 201 \\ RICHMOND, CA $94804-4698$}

January 13, 1998

\section{MEMORANDUM}

SUBJECT: $\quad$ Summary of United Heckathorn Post-Remedial

Mussel and Surface Water Sampling

FROM:

Andrew Lincoff, PMD-2

Regional Laboratory

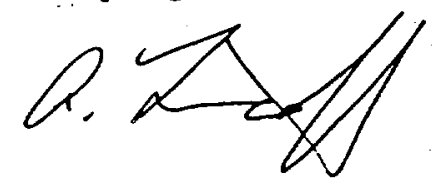

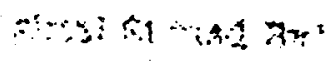

TO:

Dick Vesperman, SFD-7-3

Remedial Project Manager

Attached is the Field Sampling Summary for the post-remedial mussel and surface water sampling at the United Heckathorn Superfund Site in Richmond, California. Transplanted California mussels were deployed at four locations in Richmond Harbor in September, 1997. On January 6 and 7, 1998, seawater samples, resident mussels and the transplanted mussels were collected. Samples were shipped to the Battelle Marine Sciences Laboratory in Sequim, Washington for analysis. Replicate samples were taken for analysis at the Regional Laboratory. Results are expected to be available in approximately two months and will be forwarded to you in separate reports.

If you have any questions, please call me at (510) 412-2330.

Attachment

CE: LIAM ANTRIM 


\title{
Field Sampling Summary for Mussels and Surface Water at the United Heckathorn Site in \\ Richmond, California, conducted 1/6 - 1/7/98.
}

\author{
Andrew Lincoff \\ EPA Region 9 Laboratory \\ PMD-2 \\ January 13,1998
}

\section{INTRODUCTION}

This sampling event involved the collection of mussels and surface water samples from the Lauritzen Channel at the United Heckathorn Superfund Site and at other locations in Richmond Harbor in Richmond, California.

Sampling was performed by Andrew Lincoff and Amy Wagner of the EPA Region 9 Laboratory. Some of the mussels retrieved had been transplanted in September, 1997 with the assistance of Liam Antrim, of the Battelle Marine Sciences Laboratory, EPA's Superfund Program contractor.

Sampling was performed in accordance with Battelle's "United Heckathorn PostRemediation Field Monitoring Plan" (FSP), dated February 5, 1997, with minor deviations discussed herein. The most significant change was that additional replicate samples were taken for analysis by the EPA Regional Laboratory in order to perform an inter-laboratory comparison to provide additional information regarding the accuracy of the results.

\section{OBJECTIVE}

EPA conducted this field sampling as part of the oversight of a final Remedial Action under the Comprehensive Environmental Response, Compensation, and Liability Act (CERCLA or Superfund) at the United Heckathorn Site in Richmond, California. The sampling effort involved collecting physical environmental samples to analyze for the presence of hazardous substances.

The United Heckathorn Site was used to formulate pesticides from approximately 1947 to 1966. Soils at the Site and sediments in Richmond Harbor were contaminated with various chlorinated pesticides, primarily DDT, as a result of these pesticide formulation activities. The final remedy contained in EPA's October, 1994 Record of Decision addressed remaining hazardous substances, primarily in the marine environment. The major marine components of the selected remedy included:

- Dredging of all soft bay mud from the Lauritzen Channel and Parr Canal, with offsite disposal of dredged material. 
- Marine monitoring to verify the effectiveness of the remedy.

The first component of the remedy selected in the ROD called for dredging all "young bay mud" from those channels in Richmond Harbor which contained average DDT concentrations greater than $590 \mathrm{ppb}$ (dry wt.). The dredging was completed in April, 1997. The short-term monitoring, performed according to EPA's September 5, 1996 FSP, consisted of sediment chemistry monitoring to ensure that the average sediment concentration after dredging was below the cleanup level selected in the ROD. This monitoring was completed shortly prior to the placement of the sand cap in April, 1997.

Long-term monitoring is addressed by Battelle's February 5, 1997 FSP. The purpose of the long-term monitoring is to demonstrate the effectiveness of the remedy. Prior to the remediation, mussels in the Lauritzen Channel contained the highest levels of DDT and dieldrin in the State, and surface water exceeded EPA's Ambient Water Quality Criteria for DDT by a factor of 50. Lower but still elevated levels were found in mussels and surface water in the Santa Fe Channel. It was concluded in EPA's Remedial Investigation that these elevated levels were the result of continuous flux from contaminated sediments. Approximately $98 \%$ of the mass of DDT in sediments in Richmond Harbor was removed by the remedial dredging. The long-term monitoring will demonstrate whether this action has succeeded in reducing the levels of DDT in mussels and surface waters.

Battelle's FSP included monitoring using both transplanted California mussels and resident Bay mussels. The transplanted mussels were deployed in September and retrieved after approximately four months of exposure. The length of the deployment and seasonal timing were chosen to match the protocol used by the California State Mussel Watch Program, in order to permit comparison with the State's results over the past 15 years. Both transplanted and resident mussels will be analyzed to determine any difference. The results should be comparable. If the resident mussels have higher burdens, it may be due to past exposure. If the results are the same, only resident mussels will be collected in the future.

Laboratory results are expected from Battelle in approximately one month and will be provided in a report from Battelle in approximately two months. In addition, the EPA Regional Laboratory will perform an inter-laboratory comparison to provide additional information on the accuracy of the analyses. Replicates of the samples taken for analysis by Battelle will be analyzed by the Regional Laboratory with results expected in late March, 1998.

\section{SAMPLE PLAN AMENDMENTS}

The following deviations from the sample plan were made.

1. The FSP called for samples to be analyzed only by EPA's Superfund contractor, Battelle. In order to investigate the accuracy of the low-level seawater and tissue results, it was 
decided to take additional sample volumes for analysis by the EPA Regional Lab in Richmond, California. These samples were taken at the same locations and at the same time as the Battelle samples.

2. The FSP called for ambient salinity measurements to be made during sampling. These were mistakenly not performed in the field, but will be performed by Battelle in the laboratory.

3. When the transplanted mussels were deployed in September 1997, a second set was hung beneath the Ford automotive plant for duplication in case of vandalism at Station 303.1. As none of the mussels were disturbed, the additional set (called $303.1 \mathrm{X}$ in the field log) was discarded.

\section{FIELD NOTES AND OBSERVATIONS}

1. Samples were taken on January 6 and 7, 1997 at low tide. The weather during the sampling was calm with clouds and occasional light rain. The ambient water temperature was 12 $\mathrm{C}$ at all sample locations.

2. Factors which may influence the results included ongoing dredging in Richmond Harbor and pier maintenance at the Levin Terminal in the Lauritzen Channel. The Richmond Harbor deepening project has been ongoing since the fall of 1997. The dredging started in the upper Santa Fe Channel, near site 303.4, and was near Brooks Island and Point Potrero when the samples were retrieved. The effect of the dredging during the mussel deployment is uncertain. The dredging probably resuspended sediment containing some DDT and dieldrin which could raise values. On the other hand, the dredging removed most of the remaining $2 \%$ of the mass of DDT from Richmond Harbor not removed by the Superfund Remedy. Thus the results could be lower than they would have been without the deepening project.

Another less likely potential influence was the replacement of piles at the Levin Pier during the retrieval of samples. Conceivably, the pile driving could have resuspended sediment beneath the pier and increased the pesticide load in mussels and seawater samples.

3. The sample station numbers, locations, date and times, and other information are shown in Figure 1 and listed in Table 1, below. Location coordinates were determined using GPS with differential correction. As discussed in the FSP, the station numbers are those used by the California Mussel Watch Program. Station 303.1 is at the entrance to the Richmond Inner Harbor Channel near the old Ford automotive plant. Mussels were deployed and collected from the western-most of the large dolphins near the plant. Station 303.2 is on the eastern side of the Laurtizen near its mouth. Mussels were deployed from pilings beneath the Levin Dock near the northern end of a large wooden fender structure. Station 303.3 is approximately $2 / 3$ of the way up the Lauritzen Channel, on the eastern side. Mussels were hung from the southern end of a small wooden pier which extends out into the channel. This location is very close to where the highest levels of pesticide residues were removed from the Heckathorn Site. Station 303.4 is in 
the upper Santa Fe Channel at the far western end of a large covered floating marina on the northern side.

Table 1

Mussel and Seawater Sample Locations

\begin{tabular}{|c|c|c|c|c|}
\hline Station & Date & Time & Location & Remarks \\
\hline 303.1 & $1 / 6 / 98$ & 1235 & $\begin{array}{l}3754^{\prime} 32.8^{\prime \prime} \mathrm{N} \\
12221^{\prime} 34.5^{\prime \prime} \mathrm{W}\end{array}$ & Richmond Channel \\
\hline 303.2 & $1 / 7 / 98$ & 1245 & $\begin{array}{l}3755^{\prime} 12.6^{\prime \prime} \mathrm{N} \\
12222^{\prime} 01.2^{\prime \prime} \mathrm{W}\end{array}$ & $\begin{array}{l}\text { Lauritzen South } \\
\text { EPA QA/QC Mussels }\end{array}$ \\
\hline 303.3 & $1 / 6 / 98$ & 1315 & $\begin{array}{l}3755^{\prime} 22.5^{\prime \prime} \mathrm{N} \\
12221^{\prime} 59.9^{\prime \prime} \mathrm{W}\end{array}$ & $\begin{array}{l}\text { Lauritzen North } \\
\text { Battelle Blind Dup. Seawater }\end{array}$ \\
\hline 303.4 & $1 / 6 / 98$ & 1355 & $\begin{array}{l}3755^{\prime} 21.53^{\prime \prime} \mathrm{N} \\
12221^{\prime} 18.37^{\prime \prime} \mathrm{W}\end{array}$ & $\begin{array}{l}\text { Santa Fe } \\
\text { Battelle and EPA MS/MSD Seawater }\end{array}$ \\
\hline
\end{tabular}

Seawater, transplanted California Mussels, and resident Bay mussels were collected at each station for analysis by Battelle and the EPA Regional Laboratory. At each station three 2 liter replicate seawater samples were collected for analysis by Battelle, and two 1 liter replicate seawater samples were collected for EPA. At station 303.4, two additional 2 liter seawater samples were collected for Battelle QA/QC, and two additional 1 liter samples were collected for EPA QAVQC. An additional single 2 liter blind duplicate of seawater sample 303.3 was collected and shipped to the Battelle Lab with the fictitious station number 303.5.

At each station, approximately 60 transplanted mussels and 60 resident mussels were collected. Approximately 45 of these were sent to Battelle and the remainder (approximately 15) will be analyzed by the EPA Regional Lab. The 45 mussels per sample sent to Battelle is large enough for any sample to be selected by Battelle for laboratory QA/QC. At station 303.2 additional resident mussels were collected so that a total of 27 were retained for the EPA Regional Lab. This sample was designated for EPA mussel QA/QC.

The resident mussels were all collected near the surface, which at the collection times and dates was approximately 1 foot above Mean Lower Low Water $(+1 \mathrm{ft}$ MLLW) for the samples collected from pilings at stations 303.1,303.2, and 303.3. At station 303.4, the mussels were collected near the surface from a floating dock. The transplanted mussels were deployed at the following approximate depths: 303.1, -3 ft MLLW; 303.2, -3 ft. MLLW, 303.3, -6 ft MLLW. At station 303.4 the transplanted mussels were hung from a floating dock, and were always approximately $8 \mathrm{ft}$. below sea level. 
Figure 1

Sample Locations 1/6 - 1/7/98

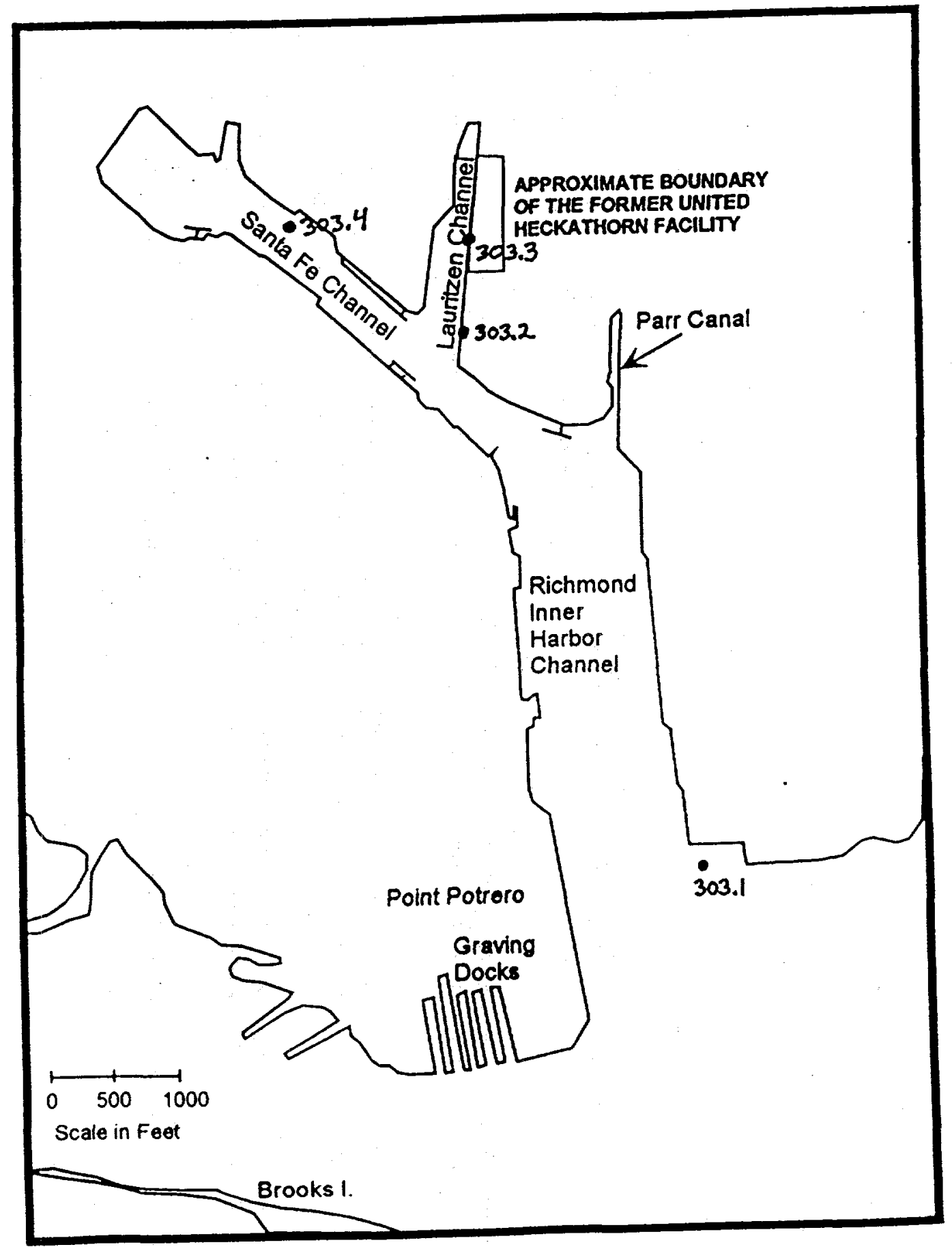




\section{APPENDIX B}

ANALYTICAL RESULTS FROM

WATER AND TISSUE SAMPLES 


\section{QAVC SUMMARY}

PROJECT:

PARAMETER:

LABORATORY:

MATRIX:

SAMPLE CUSTODY:
Heckathorn Biomonitoring

Pesticides and Total Lipids

Battelle/Marine Sciences Laboratory, Sequim, Washington

Tissues

Eight mussel tissue samples were received on 1/9/98. All containers were received in good condition. The cooler temperature on arrival was $0.4^{\circ} \mathrm{C}$. Samples were assigned a Battelle Central File (CF) identification number (1142) and were entered into Battelle's log-in system.

QAVC DATA QUALITY OBJECTIVES:

\begin{tabular}{|c|c|c|c|c|c|}
\hline Analyte & $\begin{array}{c}\text { Extraction } \\
\text { Method }\end{array}$ & $\begin{array}{c}\text { Analytical } \\
\text { Method }\end{array}$ & $\begin{array}{l}\text { Range of } \\
\text { Recovery }\end{array}$ & $\begin{array}{c}\text { Relative } \\
\text { Precision } \\
\end{array}$ & $\begin{array}{c}\text { Achieved } \\
\text { Detection Limit } \\
\text { (ng/L) }\end{array}$ \\
\hline 2,4'-DDE & $\mathrm{MeCl}_{2}$ & GC-ECD & $40-120 \%$ & $\pm 30 \%$ & 0.26 \\
\hline Dieldrin & $\mathrm{MeCl}_{2}$ & GC-ECD & $40-120 \%$ & $\pm 30 \%$ & 0.52 \\
\hline $4,4^{\prime}-\mathrm{DDE}$ & $\mathrm{MeCl}_{2}$ & GC-ECD & $40-120 \%$ & $\pm 30 \%$ & 0.19 \\
\hline $2,4^{\prime}-\mathrm{DDD}$ & $\mathrm{MeCl}_{2}$ & GC-ECD & $40-120 \%$ & $\pm 30 \%$ & 0.25 \\
\hline $4,4^{\prime}-\mathrm{DDD}$ & $\mathrm{MeCl}_{2}$ & GC-ECD & $40-120 \%$ & $\pm 30 \%$ & 0.26 \\
\hline $2,4^{\prime}$-DDT & $\mathrm{MeCl}_{2}$ & GC-ECD & $40-120 \%$ & $\pm 30 \%$ & 0.18 \\
\hline $4,4^{\prime}$-DDT & $\mathrm{MeCl}_{2}$ & GC-ECD & $40-120 \%$ & $\pm 30 \%$ & 0.15 \\
\hline Total Lipids & $\mathrm{CHCl}_{3}$ & Gravimetric & NA & $\pm 30 \%$ & NA \\
\hline
\end{tabular}

METHOD:

Chlorinated pesticides were analyzed according to a Battelle SOP based on EPA Method 8081 (EPA 1986) with modifications based on Krahn et al. (1988). Tissue samples were macerated and extracted with methylene chloride. Interferences were removed by aluminum/silicon column chromatography followed by high-performance liquid chromatography (HPLC) clean-up. Sample extracts were then transferred to cyclohexane and analyzed by capillary-column (DB-1701) gas chromatography with electron-capture detection (GC/ECD). Total lipids were determined according to the Bligh et al. (1959) method, modified to accommodate a smaller sample size. Lipids were extracted from separate aliquots of tissue samples using chloroform and the lipid weight obtained gravimetrically.

HOLDING TIMES: All extractions and analyses were conducted within target holding times: 14 days to extraction (refrigerated, not frozen), and 40 days to analysis after extraction. Samples were received on $1 / 9 / 98$ and held at $4^{\circ} \mathrm{C}$. Samples were extracted on $1 / 21 / 98$, HPLC cleanup was conducted on $1 / 22 / 98$, and GC analysis took place between 1/23/98 and 1/27/98. Lipid extractions were conducted on 1/22/98. 


\section{QAVC SUMMARY}

DETECTION LIMITS: Detection limits were determined by a previously conducted MDL study where replicates were analyzed and the standard deviation was multiplied by the Student's-t value for the number of replicates.

\author{
BLANKS/BLANK \\ SPIKES:
}

REPLICATES:

MATRIX SPIKES:

REFERENCES:
One procedural blank and two blank spikes were analyzed. All analytes were undetected in the blank. Blank spike recoveries of the two spiked analytes of interest, dieldrin and $4,4^{\prime}$-DDT, were within the target range of $40 \%-120 \%$.

One tissue sample 1142HB-19 (303.3T) was analyzed in duplicate. Precision for duplicate analyses are reported by calculating the relative percent difference (RPD) of replicate results. RPDs for all analytes of interest ranged from $0 \%$ to $8 \%$, and were all within the QC limits of $\pm 30 \%$.

A matrix spike and matrix spike duplicate were analyzed using sample 1142HB-21(303.4T). Recoveries of the two spiked analytes of interest, dieldrin and $4,4^{\prime}$-DDT, were within the target range of $40 \%-120 \%$ in both the MS and MSD. The RPD between the MS and MSD was $<30 \%$ for both dieldrin and 4,4'-DDT.

Bligh, E.G., and W.J. Dyer. 1959. A Rapid Method of Total Lipid Extraction and Purification. Canadian Journal of Biochemistry and Physiology. 37:8 911-917.

Krahn, M.M, CA Wigren, R.W. Pearce, S.K. Moore, R.G. Bogar, W. D. McLeod, Jr., S.L. Chan, and D.W. Brown. 1988. New HPLC Cleanup and Revised Extraction Procedures for Organic Contaminants. NOAA Technical Memorandum MNFS F/NWC-153. Standard Analytical Procedures of the NOAA National Facility, 1988. National Oceanic and Atmospheric Administration, National Marine Fisheries Service, Seattle, WA.

U.S. EPA. 1986 (Revised 1990). Test Methods for Evaluating Solid Waste, Physical/Chemical Methods, SW-846. 3rd ed. U.S. Environmental Protection Agency, Office of Solid Waste and Emergency Response, Washington, D.C. 
BATTELLE MARINE SCIENCES LABORATORY

1529 West Sequim Bay Road

Sequim, WA 98382-9099

$360 / 681-3643$

HECKATHORN

Pesticides in Tissue

Samples Received 1/9/98

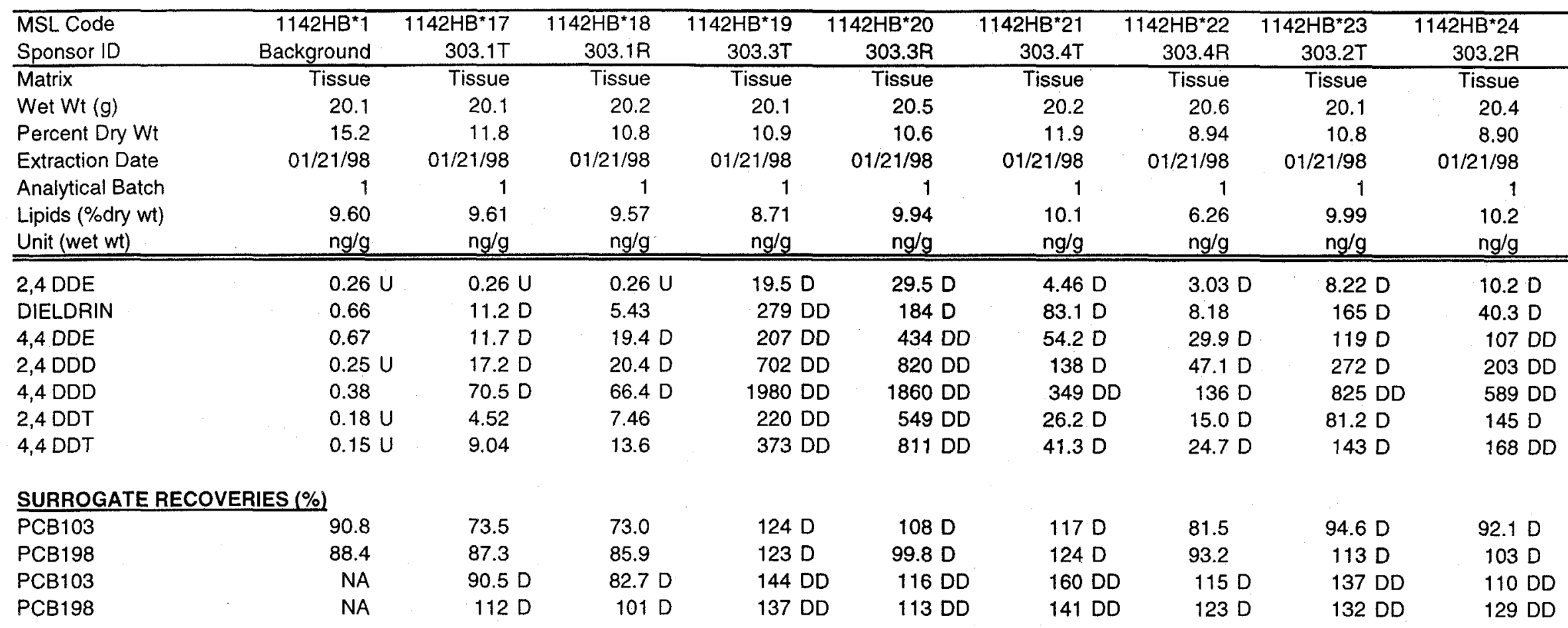

D 9X Dilution

DD 100X Dilution

U Not detected at or above DL shown

H. Nitivan

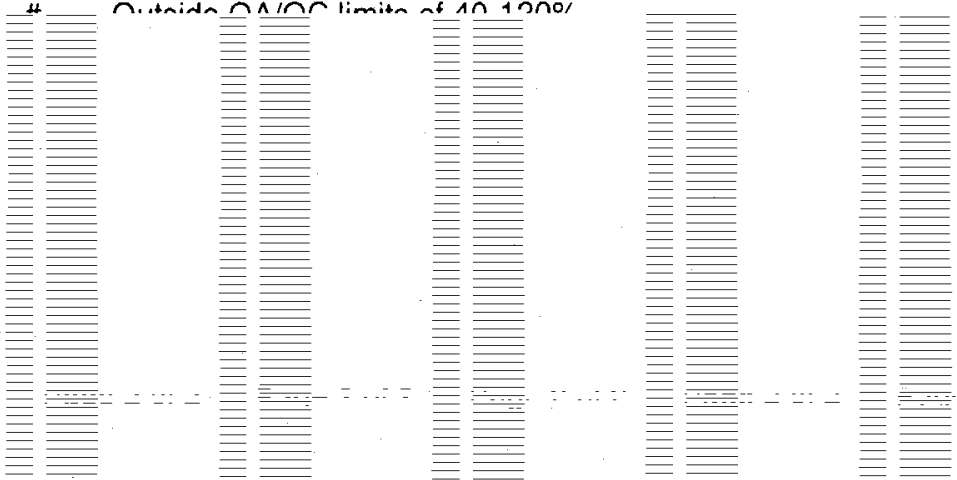




\section{BATTELLE MARINE SCIENCES LABORATORY}

1529 West Sequim Bay Road

Sequim, WA 98382-9099

$360 / 681-3643$

\section{HECKATHORN}

Pesticides in Tissue

Samples Received 1/9/98

\begin{tabular}{|c|c|c|c|c|c|c|c|c|c|c|}
\hline & & $B S A$ & & & $B S B$ & & & & DUP & \\
\hline $\begin{array}{l}\text { MSL Code } \\
\text { Sponsor ID }\end{array}$ & Blank & $\begin{array}{r}\text { Blank } \\
\text { Spike A }\end{array}$ & $\begin{array}{r}\text { Spike } \\
\text { Amount }\end{array}$ & $\begin{array}{r}\text { Percent } \\
\text { Recovery }\end{array}$ & $\begin{array}{r}\text { Blank } \\
\text { Spike B }\end{array}$ & $\begin{array}{r}\text { Spike } \\
\text { Amount }\end{array}$ & $\begin{array}{r}\text { Percent } \\
\text { Recovery }\end{array}$ & $\begin{array}{r}1142 \mathrm{HB}^{*} 19 \\
\text { 303.3 Trans }\end{array}$ & $\begin{array}{l}1142 \mathrm{HB}^{*} 19 \\
303.3 \text { Trans }\end{array}$ & RPD \\
\hline Matrix & Tissue & Tissue & & & Tissue & & & Tissue & Tissue & \\
\hline Wet Wt $(g)$ & NA & NA & & & NA & & & 20.1 & 20.1 & \\
\hline Percent Dry Wt & NA & NA & & & NA & & & 10.9 & 10.9 & \\
\hline Extraction Date & $01 / 21 / 98$ & $01 / 21 / 98$ & & & $01 / 21 / 98$ & & & $01 / 21 / 98$ & $01 / 21 / 98$ & \\
\hline Analytical Batch & 1 & 1 & & & 1 & & & 1 & 1 & \\
\hline Lipids (\%dry wt) & NA & NA & & & NA & & & 8.71 & 8.71 & \\
\hline Unit (wet wt) & $\mathrm{ng} / \mathrm{g}$ & $\mathrm{ng} / \mathrm{g}$ & $\mathrm{ng} / \mathrm{g}$ & $\%$ & $\mathrm{ng} / \mathrm{g}$ & $\mathrm{ng} / \mathrm{g}$ & $\%$ & $\mathrm{ng} / \mathrm{g}$ & $\mathrm{ng} / \mathrm{g}$ & $\%$ \\
\hline 2,4 DDE & $0.26 U$ & $0.26 U$ & NS & NA & $0.26 U$ & NS & NA & $19.5 \mathrm{D}$ & $19.2 \mathrm{D}$ & $2 \%$ \\
\hline DIELDRIN & $0.52 U$ & 4.57 & 5.00 & $91 \%$ & 4.30 & 5.00 & $86 \%$ & $279 \mathrm{DD}$ & $257 \mathrm{DD}$ & $8 \%$ \\
\hline 4,4 DDE & $0.19 \cup$ & $0.19 \mathrm{U}$ & NS & NA & $0.19 \mathrm{U}$ & NS & NA & $207 \mathrm{DD}$ & $207 \mathrm{DD}$ & $0 \%$ \\
\hline $2,4 \mathrm{DDD}$ & $0.25 \mathrm{U}$ & $0.25 \mathrm{U}$ & NS & NA & $0.25 \mathrm{U}$ & NS & NA & 702 DD & 711 DD & $1 \%$ \\
\hline 4,4 DDD & $0.26 \mathrm{U}$ & $0.26 \mathrm{U}$ & NS & NA & $0.26 U$ & NS & NA & $1980 \mathrm{DD}$ & $1980 \mathrm{DD}$ & $0 \%$ \\
\hline 2,4 DDT & $0.18 U$ & $0.18 \mathrm{U}$ & NS & NA & $0.18 \mathrm{U}$ & NS & NA & $220 \mathrm{DD}$ & $219 \mathrm{DD}$ & $0 \%$ \\
\hline 4,4 DDT & $0.15 U$ & 5.24 & 5.00 & $105 \%$ & 6.02 & 5.00 & $120 \%$ & $373 \mathrm{DD}$ & $371 \mathrm{DD}$ & $1 \%$ \\
\hline
\end{tabular}

\section{SURROGATE RECOVERIES (\%)}

\begin{tabular}{llll}
\hline PCB103 & 90.1 & 107 & 97.2 \\
PCB198 & 93.4 & 113 & 103
\end{tabular}

124 \#D

127 \#D

PCB103

03

123 \#D

123 \#D

PCB198

137 \#DD 140 \#DD

\footnotetext{
D $9 \times$ Dilution

DD $100 \times$ Dilution

$\mathrm{U}$ Not detected at or above $\mathrm{DL}$ shown

\# Outside QAVQC limits of $40-120 \%$
}

Note: PCB 198 is surrogate for the target analytes; target analyte concentrations are corrected using the PCB 198 percent recovery. 


\section{BATTELLE MARINE SCIE}

1529 West Sequim Bay Ro

Sequim, WA 98382-9099

$360 / 681-3643$

\section{HECKATHORN}

Pesticides in Tissue

Samples Received 1/9/98

\begin{tabular}{|c|c|c|c|c|c|c|c|c|}
\hline & & $M S A$ & & & $M S B$ & & & \\
\hline MSL Code & $1142 \mathrm{HB}^{*} 21$ & $1142 \mathrm{HB}^{\star} 21$ & Spike & Percent & $1142 \mathrm{HB}^{*} 21$ & Spike & Percent & \\
\hline Sponsor ID & $303.4 \mathrm{~T}$ & Spike A & Amount & Recovery & Spike B & Amount & Recovery & RPD \\
\hline Matrix & Tissue & Tissue & & & Tissue & & & \\
\hline Wet Wt $(g)$ & 20.2 & 20.0 & & & 20.4 & & & \\
\hline Percent Dry Wt & 11.9 & 11.9 & & & 11.9 & & & \\
\hline Extraction Date & $01 / 21 / 98$ & $01 / 21 / 98$ & & & $01 / 21 / 98$ & & & \\
\hline Analytical Batch & 1 & 1 & & & 1 & & & \\
\hline Lipids (\%dry wt) & 10.1 & 10.1 & & & 10.1 & & & \\
\hline Unit (wet wt) & $\mathrm{ng} / \mathrm{g}$ & $\mathrm{ng} / \mathrm{g}$ & $\mathrm{ng} / \mathrm{g}$ & $\%$ & $\mathrm{ng} / \mathrm{g}$ & $\mathrm{ng} / \mathrm{g}$ & $\%$ & $\%$ \\
\hline $2,4 \mathrm{DDE}$ & $4.46 \mathrm{D}$ & $5.07 \mathrm{D}$ & NS & NA & $5.60 \mathrm{D}$ & NS & NA & \\
\hline DIELDRIN & $83.1 \mathrm{D}$ & $85.9 \mathrm{D}$ & 5.00 & $56 \%$ & 86.6 D & 4.90 & $71 \%$ & $24 \%$ \\
\hline 4,4 DDE & $54.2 \mathrm{D}$ & $52.7 \mathrm{D}$ & NS & NA & $54.2 \mathrm{D}$ & NS & NA & \\
\hline 2,4 DDD & $138 \mathrm{D}$ & $135 \mathrm{D}$ & NS & NA & $141 \mathrm{D}$ & NS & NA & \\
\hline 4,4 DDD & 349 DD & $332 \mathrm{DD}$ & NS & NA & 352 DD & NS & NA & \\
\hline 2,4 DDT & $26.2 \mathrm{D}$ & $7.01 \mathrm{D}$ & NS & NA & $26.5 \mathrm{D}$ & NS & NA & \\
\hline 4,4 DDT & $41.3 \mathrm{D}$ & $44.7 \mathrm{D}$ & 5.00 & $68 \%$ & 45.3 D & 4.90 & $82 \%$ & $18 \%$ \\
\hline
\end{tabular}

\section{SURROGATE RECOVERI}

PCB103

PCB198

$117 \mathrm{D}$

$115 \mathrm{D}$

PCB103

PCB198

\begin{tabular}{ll}
\hline $\mathrm{D}$ & $9 \times$ Dilution \\
$\mathrm{DD}$ & $100 \times$ Dilution \\
$U$ & Not detected at or ab. \\
$\#$ & Outside QAQC limits \\
Note: & PCB 198 is surrogat
\end{tabular}




\section{QAVC SUMMARY}

\author{
PROJECT: \\ PARAMETER: \\ LABORATORY: \\ MATRIX:
}

SAMPLE CUSTODY:

\author{
Heckathorn Biomonitoring \\ Pesticides \\ Battelle/Marine Sciences Laboratory, Sequim, Washington \\ Water
}

Fifteen water samples in three coolers were received on 1/9/98. All containers were received in good condition. Cooler temperatures upon arrival were as follows:

Sample 303.1 (3 replicates): $4.2^{\circ} \mathrm{C}$

Samples 303.3, 303.2 ( 3 replicates of each), $303.5: 1.9^{\circ} \mathrm{C}$

Sample 303.4 ( 3 replicates, MS, MSD): $2.1^{\circ} \mathrm{C}$

Samples were assigned a Battelle Central File (CF) identification

number (1142HB) and were entered into Battelle's log-in system.

\section{QAVC DATA QUALITY OBJECTIVES:}

\begin{tabular}{lccccc}
\multicolumn{1}{c}{ Analyte } & $\begin{array}{c}\text { Extraction } \\
\text { Method }\end{array}$ & $\begin{array}{c}\text { Analytical } \\
\text { Method }\end{array}$ & $\begin{array}{c}\text { Range of } \\
\text { Recovery }\end{array}$ & $\begin{array}{c}\text { Relative } \\
\text { Precision }\end{array}$ & $\begin{array}{c}\text { Achieved } \\
\text { Detection Limit } \\
\text { (ng/L) }\end{array}$ \\
2,4'-DDE & $\mathrm{MeCl}_{2}$ & GC-ECD & $40-120 \%$ & $\pm 30 \%$ & 0.03 \\
Dieldrin & $\mathrm{MeCl}_{2}$ & GC-ECD & $40-120 \%$ & $\pm 30 \%$ & 0.01 \\
4,4'-DDE & $\mathrm{MeCl}_{2}$ & GC-ECD & $40-120 \%$ & $\pm 30 \%$ & 0.03 \\
$2,4^{\prime}-\mathrm{DDD}$ & $\mathrm{MeCl}_{2}$ & GC-ECD & $40-120 \%$ & $\pm 30 \%$ & 0.11 \\
4,4'-DDD & $\mathrm{MeCl}_{2}$ & GC-ECD & $40-120 \%$ & $\pm 30 \%$ & 0.05 \\
2,4'-DDT & $\mathrm{MeCl}_{2}$ & GC-ECD & $40-120 \%$ & $\pm 30 \%$ & 0.05 \\
4,4'-DDT $^{4}$ & $\mathrm{MeCl}_{2}$ & GC-ECD & $40-120 \%$ & $\pm 30 \%$ & 0.04
\end{tabular}

METHOD: $\quad$ Chlorinated pesticides were analyzed according to a Battelle SOP based on EPA Method 8081 (EPA 1986). Water samples were extracted with methylene chloride. Interferences were removed by aluminum/silicon column chromatography. Sample extracts were then transferred to cyclohexane and analyzed by capillary-column gas chromatography with electron-capture detection (GC/ECD).

HOLDING TIMES: $\quad$ All extractions and analyses were conducted within target holding times: 14 days to extraction, and 40 days to analysis after extraction. Samples were received on $1 / 9 / 98$ and held at $4^{\circ} \mathrm{C}$. Samples were extracted on $1 / 12 / 98$ and $1 / 14 / 98$ and analyzed between 1/15/98 and 1/22/98.

DETECTION LIMITS: Detection limits were determined by a previously conducted MDL study where replicates were analyzed and the standard deviation was multiplied by the Student's-t value for the number of replicates.

SURROGATES:

Recoveries of one or both of the two surrogate compounds (PCB 103 and PCB 198) exceeded data quality limits of $40 \%-120 \%$ in eight of the samples and in four of the QC samples. Samples 1142HB-9 (303.4) and $1142 \mathrm{HB}-15$ (303.2) required additional drying and evaporation steps to remove residual water. This extra handling of the samples could account for the low recoveries of both surrogates. Recoveries of both surrogates in samples 1142HB-7 (303.3) and 1142HB-13 MSD (303.4) were low, possibly due to lab mishaps where portions of the samples may have been lost. The other samples had at least one surrogate (PCB 198) within recovery criteria. Because the more volatile of the two surrogates was lost, the low recovery may be due to extra 


\section{QAVC SUMMARY}

BLANKS/BLANK SPIKES:

MATRIX SPIKES:

REPLICATES:

REFERENCES: evaporation steps to achieve a low final sample volume of $0.2 \mathrm{~mL}$. All data were surrogate-corrected; therefore, the low recoveries do not affect the reported analyte data.

Two procedural blanks were analyzed. All analytes except 4,4'-DDE in Blank 1were undetected. Blank spike recoveries of the two spiked analytes of interest, dieldrin and $4,4^{\prime}$-DDT, were within the target range of $40 \%-120 \%$.

A matrix spike and matrix spike duplicate were analyzed using the samples provided (two additional replicates of sample no. 303.4). Recoveries of the two spiked analytes of interest, dieldrin and 4,4'-DDT, were within the target range of $40 \%-120 \%$ in the MS. In the MSD, dieldrin was within the QC range, but 4,4'-DDT exceeded recovery criteria (129\%).

Four water samples were provided in triplicate, with an additional blind duplicate of sample 303.3 (sample 303.5). Precision for triplicate analyses is reported by calculating the relative standard deviation (RSD) of replicate results. RSDs for all analytes of interest were variable, ranging from $2 \%$ to $82 \%$.

U.S. EPA. 1986 (Revised 1990). Test Methods for Evaluating Solid Waste, Physical/Chemical Methods, SW-846. 3rd ed. U.S. Environmental Protection Agency, Office of Solid Waste and Emergency Response, Washington, D.C. 
BATTELLE MARINE SCIENCES LABORATORY

1529 West Sequim Bay Road

Sequim, WA 98382-9099

$360 / 681-3643$

HECKATHORN

Pesticides in Water

Samples Received 1/9/98

\begin{tabular}{|c|c|c|c|c|c|c|c|}
\hline MSL Code & $1142 \mathrm{HB}^{*} 2$ & $1142 \mathrm{HB}^{*} 3$ & $1142 \mathrm{HB}^{*} 4$ & $1142 \mathrm{HB}^{\star} 5$ & $1142 \mathrm{HB}^{*} 6$ & $1142 \mathrm{HB}^{\star} 7$ & $1142 \mathrm{HB}^{*} 8$ \\
\hline Sponsor 10 & 303.1 & 303.1 & 303.1 & 303.3 & 303.3 & 303.3 & 303.5 \\
\hline Matrix & Water & Water & Water & Water & Water & Water & Water \\
\hline Extracted Volume $(\mathrm{mL})$ & 1830 & 1850 & 1810 & 1830 & 1850 & 1850 & 1850 \\
\hline Extraction Date & $01 / 12 / 98$ & $01 / 12 / 98$ & $01 / 12 / 98$ & $01 / 12 / 98$ & $01 / 12 / 98$ & $01 / 12 / 98$ & $01 / 12 / 98$ \\
\hline Analytical Batch & 1 & 1 & 1 & 1 & 1 & 1 & 1 \\
\hline Unit & $\mathrm{ng} / \mathrm{L}$ & $\mathrm{ng} / \mathrm{L}$ & $\mathrm{ng} / \mathrm{L}$ & $\mathrm{ng} / \mathrm{L}$ & $\mathrm{ng} / \mathrm{L}$ & $\mathrm{ng} / \mathrm{L}$ & $\mathrm{ng} / \mathrm{L}$ \\
\hline 2,4 DDE & $0.02 U$ & $0.02 \mathrm{U}$ & $0.03 \mathrm{U}$ & 0.37 & 0.39 & 1.07 & $0.02 \mathrm{U}$ \\
\hline DIELDRIN & 0.47 & 1.16 & 0.32 & 14.7 & 22.5 & $17.1 \mathrm{D}$ & $23.3 \mathrm{D}$ \\
\hline 4,4 DDE & $0.15 B$ & $0.17 \mathrm{~B}$ & $0.17 \mathrm{~B}$ & 8.57 & 15.7 & $43.5 \mathrm{D}$ & 9.78 \\
\hline $2,4 \mathrm{DDD}$ & 0.28 & 0.44 & $0.10 \mathrm{U}$ & 16.7 & 17.6 & 6.98 & $20.9 \mathrm{D}$ \\
\hline 4,4 DDD & $0.05 U$ & $0.05 \mathrm{U}$ & 0.52 & $31.3 \mathrm{D}$ & $27.8 \mathrm{D}$ & 2.28 & $54.6 \mathrm{D}$ \\
\hline 2,4 DDT & $0.05 \mathrm{U}$ & $0.05 \mathrm{U}$ & 0.22 & 7.79 & .10 .6 & 7.80 & 16.0 \\
\hline 4,4 DDT & $0.04 \mathrm{U}$ & $0.04 \mathrm{U}$ & $0.04 \mathrm{U}$ & $27.0 \mathrm{D}$ & $65.9 \mathrm{D}$ & 19.1 & $93.7 \mathrm{D}$ \\
\hline \multicolumn{8}{|c|}{ SURROGATE RECOVERIES (\%) } \\
\hline PCB103 & 55.9 & 47.4 & 52.3 & 64.8 & 86.6 & $34.5 \#$ & 57.3 \\
\hline PCB198 & 78.8 & 65.8 & 74.9 & 77.3 & 103 & 42.9 & 70.9 \\
\hline
\end{tabular}

\footnotetext{
B Analyte detected in sample is $<5 x$ blank concentration

D $5 \times$ Dilution

U Not detected at or above DL shown

\# Outside QAVQC limits of $40-120 \%$
}

Note: PCB 198 is surrogate for the target analytes; target analyte concentrations are corrected using the PCB 198 percent recovery. 
BATTELLE MARINE SCIENCES LABORATORY

1529 West Sequim Bay Road

Sequim, WA 98382-9099

HECKATHORN

$360 / 681-3643$

Pesticides in Wate

Samples Received 1/9/98

\begin{tabular}{|c|c|c|c|c|c|c|c|c|}
\hline$\overline{\text { MSL Code }}$ & $1142 \mathrm{HB}^{*} \mathrm{~g}$ & $1142 \mathrm{HB}^{*} 10$ & $1142 \mathrm{HB}^{*} 11$ & $1142 \mathrm{HB}^{*} 12$ & $1142 \mathrm{HB}^{*} 13$ & $1142 \mathrm{HB}^{*} 14$ & $1142 \mathrm{HB}^{*} 15$ & $1142 \mathrm{HB}^{*} 16$ \\
\hline Sponsor ID & 303.4 & 303.4 & 303.4 & $303.4 \mathrm{MS} \mathrm{A}$ & 303.4 MS B & 303.2 & 303.2 & 303.2 \\
\hline Matrix & Water & Water & Water & Water & Water & Water & Water & Water \\
\hline Extracted Volume $(\mathrm{mL})$ & 1840 & 1870 & 1860 & 1850 & 1590 & 1880 & 1890 & 1850 \\
\hline Extraction Date & $01 / 14 / 98$ & $01 / 14 / 98$ & $01 / 14 / 98$ & $01 / 14 / 98$ & $01 / 14 / 98$ & $01 / 14 / 98$ & $01 / 14 / 98$ & $01 / 14 / 98$ \\
\hline Analytical Batch & 1 & 1 & 1 & 1 & 1 & 1 & 1 & 1 \\
\hline Unit & $\mathrm{ng} / \mathrm{L}$ & $n g / L$ & $\mathrm{ng} / \mathrm{L}$ & $\mathrm{ng} / \mathrm{L}$ & $\mathrm{ng} / \mathrm{L}$ & $\mathrm{ng} / \mathrm{L}$ & $\mathrm{ng} / \mathrm{L}$ & $\mathrm{ng} / \mathrm{L}$ \\
\hline 2,4 DDE & $0.02 \cup$ & $0.02 \mathrm{U}$ & $0.02 U$ & $0.02 \mathrm{U}$ & $0.03 \mathrm{U}$ & $0.02 \mathrm{U}$ & $0.02 \cup$ & $0.02 \mathrm{U}$ \\
\hline DIELDRIN & 2.65 & 2.16 & 2.61 & 7.48 & 7.39 & 8.84 & 10.3 & 5.40 \\
\hline 4,4 DDE & $0.03 \mathrm{U}$ & $0.03 U$ & $0.03 \mathrm{U}$ & 1.05 & 1.09 & 2.25 & 2.24 & 2.34 \\
\hline $2,4 \mathrm{DDD}$ & 2.01 & 2.04 & 2.26 & 3.03 & 2.46 & 6.60 & 6.31 & 6.06 \\
\hline 4,4 DDD & 9.62 & 8.07 & 8.84 & 8.88 & 9.29 & 19.7 & 18.6 & 14.8 \\
\hline 2,4 DDT & 0.10 & 0.15 & $0.05 \mathrm{U}$ & $0.05 \mathrm{U}$ & 0.08 & 3.90 & 3.69 & 3.72 \\
\hline 4,4 DDT & $0.04 \mathrm{U}$ & $0.04 \mathrm{U}$ & $0.04 \mathrm{U}$ & 6.28 & 8.08 & 12.6 & 15.6 & 9.33 \\
\hline \multicolumn{9}{|c|}{ SURROGATE RECOVERIES (\%) } \\
\hline PCB103 & $26.3 \#$ & $39.9 \#$ & $37.3 \#$ & 51.3 & $19.3 \#$ & 50.8 & $27.9 \#$ & 43.3 \\
\hline PCB198 & 33.9 & 49.6 & 45.6 & 64.3 & $24.6 \#$ & 61.9 & 41.9 & 48.6 \\
\hline
\end{tabular}

B Analyte detected in sample is $<5 x$ blank concentration

D $5 \times$ Dilution

$U$ Not detected at or above DL shown

\# Outside QAVQC limits of $40-120 \%$

Note: PCB 198 is surrogate for the target analytes; target analyte concentrations are corrected using the PCB 198 percent recovery. 
BATTELLE MARINE SCIENCES LABORATORY

1529 West Sequim Bay Road

Sequim, WA 98382-9099

360/681-3643

HECKATHORN

Pesticides in Water

Samples Received 1/9/98

\begin{tabular}{|c|c|c|c|c|c|c|c|c|}
\hline & & $B S A$ & & & $B S B$ & & & \\
\hline MSL Code & Blank & Blank & Spike & Percent & Blank & Spike & Percent & Blank2 \\
\hline Sponsor ID & & Spike A & Amount & Recovery & Spike B & Amount & Recovery & \\
\hline Matrix & Water & Water & & & Water & & & Water \\
\hline Extracted Volume (mL) & 1700 & 1700 & & & 1700 & & & 1800 \\
\hline Extraction Date & $01 / 12 / 1998$ & $01 / 12 / 1998$ & & & $01 / 12 / 1998$ & & & $01 / 14 / 1998$ \\
\hline Analytical Batch & 1 & 1 & & & 1 & & & 1 \\
\hline Unit & $\mathrm{ng} / \mathrm{L}$ & $\mathrm{ng} / \mathrm{L}$ & $\mathrm{ng} / \mathrm{L}$ & $\%$ & $\mathrm{ng} / \mathrm{L}$ & $\mathrm{ng} / \mathrm{L}$ & $\%$ & $\mathrm{ng} / \mathrm{L}$ \\
\hline 2,4 DDE & $0.03 \mathrm{U}$ & $0.03 \mathrm{U}$ & NS & NA & $0.03 \mathrm{U}$ & NS & NA & $0.03 \mathrm{U}$ \\
\hline DIELDRIN & $0.01 \mathrm{U}$ & 6.61 & 5.88 & $112 \%$ & 5.10 & 5.88 & $87 \%$ & $0.01 \mathrm{U}$ \\
\hline 4,4 DDE & 0.11 & 0.65 & NS & NA & 0.96 & NS & NA & $0.03 U$ \\
\hline 2,4 DDD & $0.11 \mathrm{U}$ & $0.11 \mathrm{U}$ & NS & NA & $0.11 \mathrm{U}$ & NS & NA & $0.11 U$ \\
\hline 4,4 DDD & $0.05 \mathrm{U}$ & $0.05 U$ & NS & NA & $0.05 \mathrm{U}$ & NS & NA & $0.05 \mathrm{U}$ \\
\hline 2,4 DDT & $0.05 U$ & $0.05 U$ & NS & NA & $0.05 \mathrm{U}$ & NS & NA & $0.05 \mathrm{U}$ \\
\hline 4,4 DDT & $0.05 \mathrm{U}$ & 6.03 & 5.88 & $103 \%$ & 6.09 & 5.88 & $104 \%$ & $0.04 \mathrm{U}$ \\
\hline \multicolumn{9}{|c|}{ SURROGATE RECOVERIES (\%) } \\
\hline PCB103 & 47.5 & 58.2 & & & 44.2 & & & 50.2 \\
\hline PCB198 & 56.2 & 81.5 & & & 71.4 & & & 70.9 \\
\hline
\end{tabular}

D $5 \times$ Dilution

$U$ Not detected at or above DL shown

\# Outside QA/QC limits of $40-120 \%$

Note: PCB 198 is surrogate for the target analytes; target analyte concentrations are corrected using the PCB 198 percent recovery. 
BATTELLE MARINE SCIENCES LABORATORY

1529 West Sequim Bay Road

Sequim, WA 98382.9099

HECKATHORN

360/681-3643

Pesticides in Water

Samples Received 1/9/98

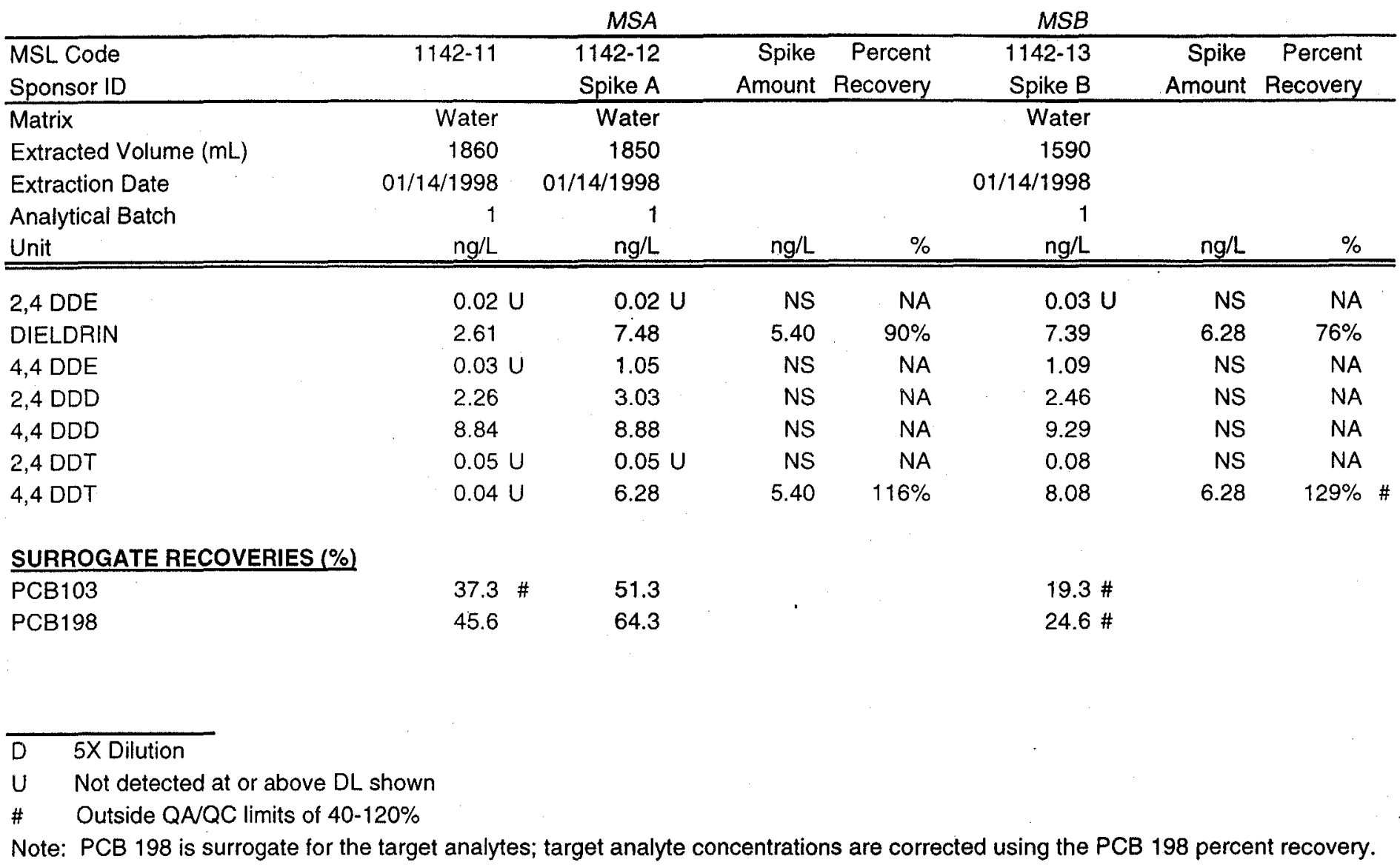




\section{DISTRIBUTION}

No. of

Copies

\section{OFFSITE}

5

R. Vesperman

U. S. Environmental Protection Agency Region IX

75 Hawthorne Street SFD-7-3

San Francisco, CA 94105

1
A. Lincoff
U. S. Environmental Protection Agency

Region IX Laboratory

1337 S. $46^{\text {th }}$ Street, Building 201

Richmond, CA 94804

1

L. D. Antrim

Olympic Coast National Marine Sanctuary

138 W. First St.

Port Angeles, WA 98362
No. of

Copies

ONSITE

7 Information Release Office K1-06

5 N.P. Kohn

1 R. K. Kropp

1 J. Q. Word 152 Sunset View Lane Sequim, WA 98382 